Hydrol. Earth Syst. Sci. Discuss., https://doi.org/10.5194/hess-2018-132

Manuscript under review for journal Hydrol. Earth Syst. Sci.

Discussion started: 19 April 2018

\title{
Compound flood potential in Europe
}

\author{
Dominik Paprotny $^{1,2}$, Michalis I. Vousdoukas ${ }^{2,3}$, Oswaldo Morales-Nápoles ${ }^{1}$, Sebastiaan N. Jonkman ${ }^{1}$, \\ and Luc Feyen ${ }^{2}$ \\ ${ }^{1}$ Department of Hydraulic Engineering, Faculty of Civil Engineering and Geosciences, Delft University of Technology, \\ Stevinweg 1, 2628 CN Delft, The Netherlands \\ ${ }^{2}$ European Commission, Joint Research Centre (JRC), Via Enrico Fermi 2749, 21027, Ispra, Italy \\ ${ }^{3}$ Department of Marine Sciences, University of the Aegean, University Hill, 41100, Mitilene, Lesbos, Greece \\ Correspondence: Dominik Paprotny (d.paprotny@tudelft.nl)
}

\begin{abstract}
The interaction between storm surges and inland runoff has been gaining increasing attention recently, as they have the potential to result in compound floods. In Europe, several flood events of this type have been recorded in the past century in Belgium, France, Ireland, Italy and United Kingdom. Here, we investigate the probability of joint occurrence of storm surges, precipitation, river discharges and waves. A coincidence of those factors have a potential to cause compound floods. We use several datasets covering most of Europe, including observations and data from the European Flood Awareness System (EFAS), ERA-Interim climate reanalysis and a regional climate model within the CORDEX framework, and carry out a statistical analysis based on copulas to assess the likelihood of joint occurrence. Further, we synthesize the joint probability of occurrence of extreme compound events, and their intensity, in the form of a composite index, thus identifying areas where compound floods could be of most concern. The results show considerable regional differences in dependency structure and the resulting joint probability of extreme surge, precipitation and river discharge events. In southern Europe the probability of joint occurrence of storm surge and precipitation is relatively high due to significant flash flood hazard. In northern Europe, along the main corridor of winter storms, dependency between surges and river discharges is higher than elsewhere, with large differences between west-facing and east-facing coasts. The occurrence of compound floods in most of the Nordic countries and along the Black Sea is very unlikely. The results allow the identification of areas at risk from compound flooding. Future studies that utilize statistical and physical methods are recommended to assess interactions between surges and inland runoff at a local scale.
\end{abstract}

\section{Introduction}

Compound floods occur when high discharge in the rivers coincide with a storm surge, resulting in water levels higher than if they would have happened separately, consequently resulting in a flood. However, this compounding effect needs to be studied locally due to its limited geographical extent and the physical interactions involved. It is therefore necessary to firstly quantify the joint probability of co-occurrence of storm surges (including waves) and flood-inducing inland phenomena (high river discharges and extreme precipitation). In this study, we analyse the dependency between these hydrometeorological phenomena to identify areas with the highest potential for compound flood occurrence. Consequently, for the purposes of this 
Hydrol. Earth Syst. Sci. Discuss., https://doi.org/10.5194/hess-2018-132

Manuscript under review for journal Hydrol. Earth Syst. Sci.

Discussion started: 19 April 2018

Hydrology and

Earth System

(c) Author(s) 2018. CC BY 4.0 License.

Sciences

Discussions

(c) (i)

analysis, we will define a compound flood as any occurrence of both extreme sea levels and high river discharges or extreme precipitation at the same time and location.

Presently, growing consideration is given to possible co-occurrence of hazards previously considered independently (Leonard et al., 2014). This attention is drawn primarily by damages caused by both coincidence of surge and excessive rainfall during tropical cyclones in the United States, including the \$150-billion deluge in Houston during hurricane Harvey in August 2017 (van Oldenborgh et al., 2017). Yet, climate of Europe differs substantially from American coasts, which are often affected by tropical storms. Even in the US, along coasts outside the paths of hurricanes there is very little dependency between coastal water levels and heavy precipitation (Wahl et al., 2015), while correlation between river flows and surges is spatially diverse (Moftakhari et al., 2017). European coasts are affected by extra-tropical cyclones, with diverse mechanisms of fluvial and pluvial floods. Climate change is expected to increase the level of hazard in many parts of the continent through increased sea levels (Vousdoukas et al., 2016), river discharges (Alfieri et al., 2015) and extreme precipitation (Lehtonen et al., 2014). At the same time, several large European cities located in river estuaries are prone to coastal floods, such as Antwerp, Hamburg, London and Rotterdam.

Historical information on past damaging floods in Europe reveal that compound events have occurred in many locations. According to HANZE database (Paprotny et al., 2018a), out of 1564 floods that occurred in 37 European countries between 1870 and 2016, 23 (1.5\%) were compound floods, recorded in six countries. The highest number of compound events, nine, were observed along the northernmost coast of the Adriatic Sea - Italian regions of Veneto and Friuli-Venezia Giulia (1927, 1951, 1952, 1953, 1957, 1966, 1986, 2008, 2012). In those situations, the events' river and coastal components merely occurred at the same time, generally without directly exacerbating total water levels. For instance, the November 1966 coastal flood in Venice (phenomena locally known as acqua alta), during which the highest water level ever recorded there was reached (194 $\mathrm{cm}$ ), happened at the same time as a disastrous flash flood $250 \mathrm{~km}$ south-west, in Florence (Tuscany), and high water in the Po river basin (137 km² inundated). Altogether, Adriatic Sea surges and coinciding high flows in the Po river resulted in approximately 25 fatalities altogether and several thousand people affected.

Another "hotspot" for compound events is the Mediterranean coast of France. Five damaging compound floods could be identified $(1872,1997,2005,2006,2013)$. In 1872 the surge coincided with eight days of rain, resulting in 18 fatalities. The December 1997 event affected the vicinity of the Rhone river estuary, which was swelled by $669 \mathrm{~mm}$ of rainfall in four days and a storm surge. The other three were flash floods caused by more than $200 \mathrm{~mm}$ of rain in $24 \mathrm{~h}$ at the time of very strong winds and high sea levels, each causing one fatality and many losses in several locations in the southern coast (and Corsica in 2013). The Western coast of France witnessed compound floods as well, for example along the Charente river in 1962 (1600 persons affected) and several rivers in the Brittany region in 2000 (600 persons affected). In both cases, a storm surge appeared during a particularly wet period, causing river flows to be elevated for a long period of time.

Remaining compound events across Europe are similar to those occurring in the western coasts of France. Surges and long periods of rainfall elevating river water levels caused compound events in Ireland in 2004 (200 persons affected) and 2009 (6800 affected), in England along The Humber in 1954 (4000) and the Bristol Channel in 1999 (1200), as well as on the river Scheldt in Belgium in 1928 (10,000). On the contrary, the causes of the 1928 Thames flood which resulted in 14 deaths in 
Hydrol. Earth Syst. Sci. Discuss., https://doi.org/10.5194/hess-2018-132

Manuscript under review for journal Hydrol. Earth Syst. Sci.

Discussion started: 19 April 2018

London and affected 4000 people, were unusual as high river discharge was a consequence of snowmelt, and the relatively moderate storm surge was exacerbated by a high tide. In the Baltic Sea, the only known instance of compound events was the storm surge along the Polish coast in 2009. There, the storm surge was not extreme, but unusually strong northerly winds pushed seawater upstream of the Odra and Vistula rivers at the time of increased runoff from rainfall. This caused inundation along Odra as far as the city of Szczecin, $70 \mathrm{~km}$ upstream.

Compound flood hazard in Europe was studied before, but in a variety of case studies using a wide array of methods and variables, covering Italy (Bevacqua et al., 2017), the Netherlands (Kew et al., 2013) and United Kingdom (Svensson and Jones, 2002, 2004). There is, therefore, a clear need for pan-European assessment of compound flood potential that includes both extreme rainfall events and high river discharges.

In this study, we utilize a large number of observational datasets and climate reanalyses to investigate dependency between hydrometeorological phenomena which contribute to compound floods along European coasts. Dependency was analysed using copula theory. The goals of this study, all undertaken for the first time on European scale, are (1) establish dependency patterns in observational data between storm surge heights, river discharges, precipitation and wave heights, (2) evaluate the ability of climatic and hydrological models to recreate the dependencies found in observations, (3) synthesize the information on joint probability and intensity of compound flood-inducing phenomena into an indicator of areas, where compound flooding is most likely to occur and more detailed, local analysis of flood hazard should be carried out.

\section{Materials and methods}

The study was carried out in three phases - each introduced in this chapter. Firstly, pan-European datasets on storm surge heights, precipitations amounts, river discharges and significant wave heights were collected. Then, pairs of variables for the same, or nearest available, location were analysed through copulas to obtain correlations and dependency structures. Both observational and modelled datasets are used, with modelled data validated based on observations. Finally, areas with the highest and lowest potential for compound flood occurrence are identified using two composite indices.

\subsection{Domain and data}

Datasets collected for this study are summarized in Table 1. Fundamental for the analysis were direct measurements (observations). Hourly records of sea levels were taken from 156 gauges, the same as used in Paprotny et al. (2016). The tidal component was removed from the data using a skew surge approach, i.e. the difference between the predicted astronomical high tide and nearest observed high water (Batstone et al., 2013). For detailed sources of the sea level data and information on how the data were processed we refer to Paprotny et al. (2016). Records of daily river discharges were collected from 1791 gauges and are the same as in Paprotny and Morales-Nápoles (2017). Finally, daily precipitation was drawn from two sources, both being gridded interpolations of measurements taken at weather stations: E-OBS with a $0.25^{\circ}$ resolution, i.e. with of cells approximately 200-600 km² over Europe (Haylock et al., 2008), and EFAS-Meteo with a $5 \mathrm{~km}$ resolution Ntegeka et al. (2013). Wave heights from 48 buoys were taken from Vousdoukas et al. (2017). 
Hydrol. Earth Syst. Sci. Discuss., https://doi.org/10.5194/hess-2018-132

Manuscript under review for journal Hydrol. Earth Syst. Sci.

Discussion started: 19 April 2018

Hydrology and

Earth System

(c) Author(s) 2018. CC BY 4.0 License.

Sciences

Discussions

(c) (i)

For a full pan-European analysis, data from several models were collected. Daily river discharges in a gridded, 5-km network were obtained from the European Flood Awareness System (EFAS), which utilizes the Lisflood hydrological model driven by meteorological data from EFAS-Meteo (Alfieri et al., 2016). Sub-daily storm surge heights were simulated by Paprotny et al. (2016) using Delft3D (Deltares, 2014) with a $0.11^{\circ}$ regular rotated-pole grid (approx. $12.5 \mathrm{~km}$ ) driven by wind and air pressure data from ERA-Interim climate reanalysis (Dee et al., 2011). Sub-daily significant wave heights were obtained from WaveWatch III simulations (Tolman, 2002) driven by ERA-Interim and carried out by Mentaschi et al. (2017), with results presented per $25 \mathrm{~km}$ coastal segments. Precipitation was taken directly from ERA-Interim, which has a $0.75^{\circ}$ resolution (approx. 2000-6000 km² cells).

Lastly, data were collected from simulations utilizing hindcasts from regional climate models within the EURO-CORDEX framework (Jacob et al., 2014). To be comparable, the different variables would need to originate from the same climate model run. Here, storm surge and river discharge simulations, made with Delft3D and EFAS, respectively, were only both available for the RCA4 regional model (Strandberg et al., 2015) coupled with the ICHEC-EC-EARTH general circulation model, realization r12i1p1. Details of those simulations can be found in Paprotny et al. (2016) and Alfieri et al. (2015). Precipitation was obtained directly from the RCA4 historical run at $0.11^{\circ}$ resolution (1970-2005).

15 The study area is the same as in Paprotny et al. (2016), which is comprised of all European coasts with the exception of outlying islands (the Azores, Madeira, the Canary Islands and Norwegian Arctic dependencies) as well as majority of Russian and Ukrainian coastline. Grid cells of the Delft3D model were connected with the geographically nearest grid cell of the other datasets. A different method was only used for linking river gauges and EFAS grid cells. For each river gauge, an EFAS grid cell with the smallest difference in catchment area within $10 \mathrm{~km}$ radius was considered corresponding to the river gauge in question.

\subsection{Statistical analysis of dependencies between variables}

The dependency between the different variables is analysed here using copulas, which are an important tool for studying dependency between hydrological and meteorological phenomena, such as relationship between flood volume and peak discharge (Salvadori and Michele, 2007), precipitation at two different locations (Schölzel and Friederichs, 2008) and precipitation amount and duration (Morales-Nápoles et al., 2017). A copula is, loosely, a joint distribution on the unit hypercube with uniform $[0,1]$ margins. Copulas are very useful models of dependence. In fact, every continuous joint distribution can be uniquely represented by a copula. In the bivariate case, random variables $X$ and $Y$ are converted into uniform [0,1] variates through their margins. The transformed variates, usually denoted as $u$ and $v$, are then fitted to one of many copula models. Various copula models are described in detail by Joe (2014). Here, we test seven different copulas in order to find one that fits best the data of interest. A summary of the copulas used in this research and their cumulative density functions are presented in Table 2. 
Hydrol. Earth Syst. Sci. Discuss., https://doi.org/10.5194/hess-2018-132

Manuscript under review for journal Hydrol. Earth Syst. Sci.

Discussion started: 19 April 2018

Some of the copulas studied model an important aspect of joint distributions known as tail dependence. The upper tail dependence coefficient $\lambda_{U}$ for two random variables $X$ and $Y$ is:

$\lambda_{U}=\lim _{u \rightarrow 1} P\left(X>F_{X}^{-1}(u) \mid Y>F_{Y}^{-1}(u)\right)=\lim _{u \rightarrow 1} P(U>u \mid V>u)$

Roughly, a value of $\lambda_{U}>0$ indicates that it is likely (more than normal) to observe values of $U$ greater than $u$ given that $V$

5 is greater than $u$ for $u$ arbitrarily close to 1 . Lower tail dependence (or in general dependence in other quadrants) would be defined similarly as eq. 1 , but then for the lower quadrant of the joint distribution. The Gaussian, Frank and Plackett copulas present no tail dependence, while Clayton presents lower tail dependence $\lambda_{L}=2^{-\frac{1}{\alpha}}$ and the Gumbel copula presents upper tail dependence $\lambda_{U}=2-2^{\frac{1}{\delta}}$. Joe-Clayton (BB7) and $t$ copulas have both upper and lower tail dependence. The investigation of these copulas covers a range of dependence structures that are usually observed in data.

As a diagnostic tool to choose the copula that best represents the dependency structure, we utilize one of the test statistics in the "Blanket Test" class discussed by Genest et al. (2009), which is the Cramèr-von Mises statistic $(M)$. The test statistic of interest for a sample of length $\mathrm{n}$ is computed as follows:

$M_{n}(\mathbf{u})=n \sum_{|u|}\left(C_{\hat{\theta}_{n}}(\mathbf{u})-B(\mathbf{u})\right)^{2}, \mathbf{u} \in[0,1]^{2}$

where $B(\mathbf{u})=\frac{1}{n} \sum_{i=1}^{n} \mathbf{1}\left(U_{i} \leq \mathbf{u}\right)$ is the empirical copula and $C_{\hat{\theta}_{n}}(\mathbf{u})$ is a parametric copula with parameter $\hat{\theta}_{n}$ estimated from

15 the sample. Notice that the statistic is the sum of squared differences between the empirical copula and the parametric estimate. If the correlation is negative, we compute the $M$ statistic for Gumbel and Clayton with the rotated copula. A copula that had the lowest $M$ statistics for a given pair of variables for a given location was considered the "best-fitting" copula and used for subsequent analyses. However, if the correlation was very weak, i.e. in the interval [-0.1,0.1], the copula type was not calculated, except for the purpose of calculating a synthetic index of compound flood potential in section 3.4. Furthermore, full marginal distributions of all variables were used to compute correlation coefficients and best-fitting copula types, rather than only the most extreme values of the distribution above a given percentile. The rationale for this important assumption is related to an analysis of the resulting dependencies and discussed in section 4.3.

\subsection{Composite indices of compound flood potential}

The various dependency structures found in the many data series of storm surge heights, precipitation amounts and river discharges are presented in the results section. Those translate into return periods of compound events, which also involve a variety of intensities along the joint distributions' margins. In order to synthesize this information to identify areas with highest potential for a hazardous compound event, we constructed two composite indices. The first is intended to represent the potential of joint occurrence of a storm surge and a flash flood, using three subindices: extreme precipitation amount, storm surge height and joint return period. The other is for the joint occurrence of a storm surge and a river flood and combines three subindices: extreme river discharge, storm surge height and joint return period. Thus, by combining two boundary conditions and joint probability, the indices distinguish areas favourable for compound flood occurrence. 
Hydrol. Earth Syst. Sci. Discuss., https://doi.org/10.5194/hess-2018-132

Manuscript under review for journal Hydrol. Earth Syst. Sci.

Discussion started: 19 April 2018

The indices are an average of a set of subindices $S_{i, c}$ for each data point $c$ along the coast:

$S_{i, c}=\frac{v_{i, c}-\min \left(V_{i}\right)}{\max \left(V_{i}\right)-\min \left(V_{i}\right)}$

where $v_{i}$ is a variable used to construct the subindex, with $i=1,2,3,4,5$, and $V_{i}=\left\{v_{i, 1}, v_{i, 2}, \ldots, v_{i, n}\right\}$ is a set of all observations of $v_{i}$. Each variable $v_{i}$ is a decimal logarithm of the following indicators:

- $v_{1}$ is the joint return period (in years) of a 10-year precipitation event occurring on the same day as a 10-year storm surge. This is calculated using the best fitting copula.

- $v_{2}$ is the daily precipitation amount (in $\mathrm{mm}$ ) with a return period of 10 years.

- $v_{3}$ is the storm surge height (daily average in $\mathrm{m}$ ) with a return period of 10 years.

- $v_{4}$ is the return period (in years) of a 10-year extreme high river discharge occurring on the same day as a 10-year storm surge. This is calculated using the best fitting copula.

- $v_{5}$ is the river discharge (daily average in $\mathrm{m}^{3} \mathrm{~s}^{-1}$ ) with a return period of 10 years.

In order words, each indicator was transformed into decimal logarithm and standardized in the interval $[0,1]$. The subindices were aggregated by a simple average into a composite index for a storm surge-flash flood combination $I_{p}$ and storm surge-river flood combination $I_{d}$ :

$15 \quad I_{p}=\frac{\left(1-S_{1}\right)+S_{2}+S_{3}}{3}$

$I_{d}=\frac{\left(1-S_{4}\right)+S_{2}+S_{5}}{3}$

The composite index can have values in the interval $[0,1] . I_{p}$ was computed for all coastal segments in Europe, while $I_{d}$ only for estuaries of rivers with a catchment area of at least $500 \mathrm{~km}^{2}$. The indices were calculated from 1990-2013 data. Precipitation amounts for the index were taken from EFAS-Meteo, river discharges from EFAS/EFAS-Meteo and storm surge heights from Delft3D/ERA-Interim.

\section{Results}

In this paper, only results calculated using a daily temporal resolution for all datasets are presented. This is for the sake of clarity and brevity, as the dependency structures in daily and 6-hourly data were found to be very similar. Supplementary Fig. 1 compares Spearman's rank correlation coefficients computed from daily and 6-hourly series for a few example pairings of variables and datasets. When correlations calculated from different data sources are compared throughout the paper, only data from overlapping time periods are used for the analysis, e.g. observations from 1990-2013 are used when comparing with results from EFAS, rather than full series starting in 1950. There were very few overlapping time series for observed surges and waves in our dataset, hence those results are excluded. 
Hydrol. Earth Syst. Sci. Discuss., https://doi.org/10.5194/hess-2018-132

Manuscript under review for journal Hydrol. Earth Syst. Sci.

Discussion started: 19 April 2018

Hydrology and

Earth System

(c) Author(s) 2018. CC BY 4.0 License.

Sciences

Discussions

(c) (i)

\subsection{Dependency structures in observational data}

Dependency between storm surge heights and precipitation amounts is presented in Fig. 1. Strongest dependency (rank correlation 0.3 and more) is observed in the west-facing coasts, such as western Great Britain, the Netherlands, western Sweden and Norway, and western Iberia. Along the coasts on the opposite side (eastern Great Britain, Sweden or Spain) the correlation is much weaker, mostly below 0.2. A notable exception is the eastern coasts of the Apennine Peninsula, where the correlation is stronger than in other parts of the Mediterranean Sea. Indeed, the highest correlation in that basin was calculated for Venice tide gauge, where, as noted in the introduction, compound events are particularly frequent. Further, there is a sharp divide in dependency structure between northern and southern Europe. In total, out of 120 gauges for which a copula type was calculated for the period 1970-2014, Frank copula was the best-fitting type for 56\% and Gumbel for 40\% (some gauges did not have comparable E-OBS precipitation grid points nearby or the rank correlation was too low). However, gauges in northern Europe show almost exclusively Frank copula dependency, while those in the south - Gumbel copula dependency. Other types of copulas appear only in a few gauges, exclusively in the south.

Dependency structures observed between storm surges and river discharges are more complex (Fig. 2). Similarly to precipitation, high correlations are observed in west-exposed coasts. Yet, higher correlation is also very noticeable along the main storm corridor in Europe, which goes from Ireland and Great Britain through the Netherlands, northern Germany, Denmark, southern Sweden, and ending in the eastern Baltic Sea coasts. In Scandinavia, the correlation visibly weakens moving north, while in Great Britain it lowers moving east. Naturally, moving from the coast to the interior of the continent the dependency also weakens, to the point that in central France or north-eastern Spain, where discharges are compared with Mediterranean tide gauges, the correlation mostly turns negative. Stark spatial patterns are also visible for best-fitting copula types. Along the aforementioned storm path the Gumbel copula dominates, and is also most frequent among all river gauges for which data is available (56\%). In Scandinavia, except southern Sweden, Frank copula is most common, and best-fitting for $20 \%$ of all gauges in Europe. Clayton copula (12\%) occurs in stations in Spain and France, usually for those with negative correlation, but also in some locations in Scandinavia. Remaining copula types (12\%) are spread without clear pattern across Europe, but appear more often in France and Spain, in gauges located further away from the coast. Examples of two most common dependency types in this analysis, Gumbel and Frank, are shown in Fig. 3.

\subsection{Validation of modelled data}

Analysis of model's performance was first carried out by validating the marginal distributions of variables obtained through ERA-Interim and EFAS-Meteo. They were compared with observed daily time series of precipitation, surges and river discharges. EURO-CORDEX data are a hindcast, hence those time series are not directly comparable with observations. The performance of models (or alternative observational data from EFAS-Meteo) for different variables is similar. Average rank correlation for storm surge heights from tide gauges compared with data calculated from Delft3D/ERA-Interim is 0.64 (19792014). Overall, surges in northern Europe were modelled more accurately than those in the Mediterranean. For river discharges in EFAS, the average correlation with river gauge observations is 0.68 (1990-2013). For precipitation (evaluated at tide gauge 
Hydrol. Earth Syst. Sci. Discuss., https://doi.org/10.5194/hess-2018-132

Manuscript under review for journal Hydrol. Earth Syst. Sci.

Discussion started: 19 April 2018

(c) Author(s) 2018. CC BY 4.0 License.

locations), the correlation between E-OBS and EFAS-Meteo is 0.65 (1990-2013), and between E-OBS and ERA-Interim is 0.56 (1979-2014). In case of precipitation, the result is affected by large differences in grid sizes (ERA-Interim is much coarser, and EFAS-Meteo much finer than E-OBS) and noticeable inaccuracies of interpolated data sets in coastal areas. Finally, the average rank correlation of observed and modelled discharges is 0.65 . Results for individual stations are presented in

Supplementary Fig. 2-4.

Three combinations of models were used to compute dependency between storm surges and precipitation, and were compared with rank correlations obtained from observations (Fig. 4). Performance of all three model combinations is similar and relatively good, with $\mathrm{R}^{2}$ in the range of 0.6-0.67. Also, in all three configurations the correlation between modelled surge and precipitation is overestimated on average compared to the observations. EURO-CORDEX data indicate the best performance, but with some visible bias, in contrast to the other two model combinations. Spatially, the differences between modelled and "observed" rank correlations are distributed very unevenly. The largest overestimation of correlation is noticeable in southern Great Britain, the Netherlands and western Iberia, with much better performance for northern Great Britain, Scandinavia and eastern coast of Italy (Supplementary Fig. 5). However, the dependency structure is largely preserved, with the best-fitting copula types being very consistent between modelled and observed data. Stations in the Mediterranean Sea with insufficient data in Fig. 1 were indicated by models as belonging to Gumbel copula type, which is consistent with other stations in southern Europe. As a result, the share of Gumbel and Frank copulas indicated as best-fitting type is estimated at 46-49\% and 47-53\%, respectively.

Models' performance in recreating the dependency between storm surges and river discharges is not as good as for precipitation. Combination of surge heights from Delft3D/ERA-Interim and discharges from EFAS is very badly correlated with dependencies found in observations (Fig. 5), with $\mathrm{R}^{2}$ equalling only 0.1. On the other hand, surges and discharges forced by CORDEX hindcast perform much better, with $\mathrm{R}^{2}$ equal to 0.36 . This is because there is a lack of sea level observations for 1970-2005 along the Mediterranean coasts of France and Spain. Models have shown particularly poor performance for river gauges in proximity to the Mediterranean Sea (Supplementary Fig. 6). Without those stations, the $\mathrm{R}^{2}$ between ERAInterim/EFAS data and observations would be 0.39. Otherwise, there is no clear pattern in the distribution of errors, though in areas most frequently affected by winter storms (corridor from Ireland to southern Sweden) the models' performance is somewhat better. The rank correlation for stations in Scandinavia is lower for models than for observations, while in France and Spain it is, in most cases, substantially larger. It should be noted that the errors originate rather in the storm surge model than in the river model, as the rank correlations from tide gauge-EFAS combination compared with rank correlations from observations give an $\mathrm{R}^{2}$ of 0.44 , while for Delft3D-river gauge combination the $\mathrm{R} 2$ is 0.17 . It can be due to the fact that a large number of river stations, mostly in France and Spain, are paired with tide gauges where storm surge series are modelled much less accurately than in the North or Baltic Seas. Exclusion of those stations (ca. $20 \%$ of total) increases $\mathrm{R}^{2}$ for Delft3D-river gauge combination from 0.17 to 0.60 .

At coastal gauge locations, model performance is also unsatisfactory in relation to river discharges. Only a limited number of stations had comparable data (78 or 43), but the relatively poor $\mathrm{R}^{2}(0.15-0.28)$ and substantial bias is noticeable (Fig. 6). In the first comparison, tide gauge series are replaced by reanalysis using Delft3D and ERA-Interim, with EFAS discharges used 
Hydrol. Earth Syst. Sci. Discuss., https://doi.org/10.5194/hess-2018-132

Manuscript under review for journal Hydrol. Earth Syst. Sci.

Discussion started: 19 April 2018

for both dependency calculations. CORDEX-generated data series mostly underestimate it. Also, the majority of modelled dependencies show Frank copula-type dependency, in contrast to Gumbel being most frequent in the 'observations'. Out of the stations available, gauges in Great Britain indicate the largest error, and those in Scandinavia relatively smaller (Supplementary Fig. 7).

\section{Dependency structures in modelled data}

Using modelled storm surges, precipitation, discharges and waves provides full coverage of European coasts, not attainable with scattered observations. Fig. 7 presents rank correlations and best-fitting copula types calculated using storm surge heights from Delft3D/ERA-Interim and precipitation from EFAS-Meteo. In general, correlations from observations (Fig. 1) blends well with model outputs, so that the geographical distribution of rank correlations between daily surge and precipitation is very similar to the observations. Highest correlations observed in west-exposed coasts and Italy, the lowest in eastern Great Britain, Iceland and south-west Baltic Sea. The distribution of best-fitting copula types is also similar, with Frank copula dominating in northern Europe (and 56\% of all coastline) and Gumbel dominating in the south (38\%). Using ERA-Interim reanalysis instead of EFAS for precipitation gives very similar results both in terms correlation and best-fitting copula types. Hindcast data from EURO-CORDEX are slightly less aligned, with some overestimation in northern Europe and eastern Mediterranean relative to the reanalysis (Supplementary Fig. 8). Nonetheless, there is an overall good match between the hindcast and the reanalysis with EFAS-Meteo, with $\mathrm{R}^{2}=0.75$ (Supplementary Fig. 8).

Dependency between storm surge heights and river discharges from Delft3D/ERA-Interim and EFAS/EFAS-Meteo, respectively, is shown in Fig. 8 (rank correlations) and Fig. 9 (best-fitting copula types). The geographical distribution of correlations for all coastal catchments is similar to those between storm surges and precipitation described in the previous paragraph, as the vast majority of storm surge data points were connected with very small, one-grid cell catchments $\left(25 \mathrm{~km}^{2}\right)$. Still, the average correlation in almost a third lower. Therefore, the second set of figures uses only EFAS grid cells (within $25 \mathrm{~km}$ distance) that have at least $500 \mathrm{~km}^{2}$ catchment area. This largely weakens the correlations with storm surges, hence no distinct patterns could be observed, though still more correlation is visible in western Spain and Portugal, along the Irish Sea and central Italy. In the vast majority of data points (84-87\% of coastline) the Gumbel copula is indicated as the most optimal to model dependency between surge and river discharge. However, using data from EURO-CORDEX, the pattern of best-fitting copula types is closer to that found in observations, with Gumbel being most optimal for 55-66\% of coastline. EURO-CORDEX data show higher rank correlations than the reanalysis in general (Supplementary Fig. 9), but both model configurations are relatively aligned, with $\mathrm{R}^{2}$ of 0.65-0.67 (Supplementary Fig. 10).

Finally, modelled significant wave heights were used to analyse correlations with storm surge heights. This combination of events does not generate a compound flood, but nonetheless could be an important contributing factor. The resulting patterns are similar to other combinations, with west-facing coasts having the highest dependency (Fig. 10). However, Icelandic and Italian coasts also stand out with high correlation. In relatively sheltered locations, such as the western Baltic Sea, Aegean Sea and Alboran Sea (westernmost part of the Mediterranean) the correlation is the lowest and mostly negative. Gumbel copula 
Hydrol. Earth Syst. Sci. Discuss., https://doi.org/10.5194/hess-2018-132

Manuscript under review for journal Hydrol. Earth Syst. Sci.

Discussion started: 19 April 2018

is the best-fitting dependency structure for the vast majority of the coastline (84\%). Frank copula (10\%) can be found only in some east-facing coasts and in the far north of Europe.

\subsection{Compound flood potential index}

The two variants of the compound flood potential index - for storm surges combined with either extreme precipitation (as a 5 proxy for flash floods) or high river discharges (as a proxy for river floods) - are presented in Fig. 11. Higher values of the index should be interpreted as an indication that local hydrometeorological conditions are more favourable for occurrence of compound flood events than in other locations. The individual components, i.e. return periods of joint occurrence and intensity of marginal events, are shown in Supplementary Fig. 13 and 14, respectively. Storm surges are the highest along the North Sea and Baltic Sea coast, and lowest in the Mediterranean region, while for extreme precipitation essentially the reverse is true - smallest precipitation amounts with a 10-year return period are recorded in northern Europe, and the highest in southern France, eastern Spain, Italy and Greece. River discharges are, very roughly, proportional to catchment size.

Return period of joint occurrence of a 10-year storm surge and 10-year extreme precipitation event differs substantially between southern Europe, where it is below 500 years (often less than 100 years), and northern parts of the continent, where it is above 1000 years. This is a result of different copula types indicated as best-fitting in the two regions (see section 3.3), with upper tail dependence in the data series from the Mediterranean region being the reason for relatively high probability of occurrence of compound flood events. The return periods of co-occurrence of surges and high water in rivers is more evenly spread, and are mostly less than 500 years along the majority of southern and western Europe's coasts. Only in the far north of the continent (Iceland, Norway, northern Baltic Sea) and along the Black Sea it is much higher, above 1000 years.

Combining the subindices together brings a complex picture (Fig. 11). Flash flood-storm surge co-occurrence is indicated as having most potential to cause a compound flood in north-western Spain and Portugal, southern France, north-west and southern Italy, Adriatic Sea coasts and Greece, and the lowest potential along the Finnish, Swedish and Icelandic coasts. It is also relatively higher along the southern and eastern shores of the North Sea. In case of rivers with catchment area of at least 500 $\mathrm{km}^{2}$, the potential for compound events is the highest along the corridor from Ireland through Great Britain, the Netherlands, north-west Germany, southern Sweden to Lithuania and Latvia. Western and southern coasts of France, north-western Portugal and Spain, and some of the rivers in the Balkans also have elevated potential for compound floods; much less so for southern parts of the Mediterranean region, and far north of Europe.

\section{Discussion}

\subsection{Composite index and past records of floods}

Compound floods are rare and diverse events, therefore it is difficult to synthesize at European scale. In the composite index, we use events with a 10-year return period, which are not particularly extreme by themselves. Yet, even with such a low threshold, actual co-occurrence of compound flood-inducing phenomena is exceedingly rare. Using Delft3D/ERA-Interim reanalysis of 
Hydrol. Earth Syst. Sci. Discuss., https://doi.org/10.5194/hess-2018-132

Manuscript under review for journal Hydrol. Earth Syst. Sci.

Discussion started: 19 April 2018

(c) Author(s) 2018. CC BY 4.0 License.

storm surge and EFAS river discharges, merely three compound events could be identified for years 1990-2013 using the aforementioned threshold. Combining surge reanalysis with ERA-Interim precipitation gives only six events with at least 10year return period on both margins for years 1979-2014, and a further two with EFAS-Meteo precipitation (1990-2013). Out of those 11 events, seven are known to have caused damages (see Table 3). Most damaging was the 1986 Venetian acqua alta, with five fatalities. Most of the compound events found in the reanalysis were located in the south of Europe, where flash floods are most common and damaging (Paprotny et al., 2018b). North-western Spain and Portugal, where both variants of the index have high values, is featured three times, and in each case there known direct losses from flood. South-western Spain (by the Gulf of Cádiz) occurs in Table 3 twice, both with recorded losses; this region has also relatively high values of both composite indices. Three events were indicated in Greece, though no information on losses were identified. Remaining compound events were found in areas with rather low values of the composite index of flash flood-storm surge co-occurrence: Iceland and north-western France.

In a further investigation into the utility of the composite index, a list of river estuaries with the highest value of the index was compiled together with past records of damaging floods (Table 4). The rivers are of variety of sizes, but all were affected by both coastal and river floods in the vicinity of their estuaries. Two (Scheldt and Ouse) have known past compound events, and flash floods were records around some of the estuaries. Further, reanalysis data has shown that some of the river floods co-occurred with minor storm surges (return period below 10 years). Hence, all 12 estuaries with the highest compound flood potential have caused damages several times in the past and could likely be affected by a compound event. All are located in north-western Europe, which can be connected with specific regional climate features. As it happens, the storm season (November-March) is also the period when flows in rivers in France, UK, Benelux countries are elevated, which a characteristic of the oceanic river regime type (Schneider et al., 2013). Snowmelt-related floods with long flood waves also occur in that period. It can be added that due to high coastal flood hazard, two estuaries (Meuse and Rhine) can be closed by storm surge barriers, similarly to the Thames (not featured among top 12), where a compound flood occurred in 1928, while others might be not as well protected (Scussolini et al., 2016). On the other hand, closure of a barrier during high water in the river might not prevent a flood (Kew et al., 2013; Zhong et al., 2012).

\subsection{Time lags in joint occurrence}

The analysis presented here only included co-occurrence of surge, precipitation or discharges at the same time, while there might be a no less hazardous situation when events occur one immediately after the other. For instance, in area affected by a flash flood, and therefore with reduced resilience, a storm surge might have more serious consequences than during a standalone occurrence. To investigate this aspect, the correlations between the different variables were recalculated, with a lag inserted into one of the series in every pair. Values of the lag, in days, that provided the highest correlation at a given location, are shown in Fig. 12, with additional 6-hourly analysis presented in Supplementary Fig. 15. In case of daily precipitation, the series without any lag gave the highest correlation with storm surge heights in 50\% of locations. In 39\% of data points along the coast, precipitation from the day before a surge had the highest correlation. However, using 6-hourly series from ERA-Interim, the largest dependency was obtained with no lag in $81 \%$ of cases, and with a 6 -hour lag in $14 \%$ of cases. Synchronization of surges 
Hydrol. Earth Syst. Sci. Discuss., https://doi.org/10.5194/hess-2018-132

Manuscript under review for journal Hydrol. Earth Syst. Sci.

Discussion started: 19 April 2018

(c) Author(s) 2018. CC BY 4.0 License.

and precipitation is, therefore, very high, except for some regions, like the southern coasts of North Sea and Baltic Sea, where the arrival of high sea levels from the ocean is delayed by the coasts of Great Britain and Denmark.

The situation is different for discharges in rivers with catchment area of at least $500 \mathrm{~km}^{2}$, as no lag results in the highest correlation only in $6 \%$ of estuaries. A lag of +1 day is observed in $44 \%$ of rivers, +2 days in $25 \%$ and +3 days or more in $15 \%$.

5 The highest lags are observed in north-western Europe, including France and the United Kingdom. Only in the far north of Europe (Iceland and northern Scandinavia) a negative lag gives the largest correlations. Similarly, lags for 6-hourly significant wave heights are mostly positive: in $50 \%$ of cases, waves occurring 6 hours or more after the surges are most highly correlated. The lag is slightly higher at coasts exposed directly to the Atlantic Ocean, though the highest values were obtained for Greece. Negative lags are confined to the Baltic Sea, where the storm surges are delayed by the time needed by the basin to fill up through the Danish Straits during windstorms.

\subsection{Uncertainties and limitations}

For the dependency analysis, the full marginal distributions of storm surge heights, precipitation, river discharges or wave heights were used. This is different approach than taken in some other studies. For instance, Wahl et al. (2015) only utilized annual maxima of surge heights or precipitation and corresponding values of the other variable within \pm 1 day range. However, there are several reasons for opting for another approach. On the theoretical level, using only the upper tail of the marginal distribution of one variable and the corresponding values on the other margin gives two separate results, themselves not independent of each other. Wahl et al. (2015) argued that they represent different mechanisms, namely moderate surges during extreme precipitation events, and moderate precipitation events during extreme surges, as evidenced by different weather patterns during those two variants of combined floods. However, such approach limits severely the number of data points, which likely caused the large variety of dependency structures observed in the aforementioned study's results.

Here, we made a comparison of the same analyses based on both the full dataset and only the upper $95^{\text {th }}$ of one of the margins. In case of precipitation, $96 \%$ of storm surge-precipitation pairs at tide gauges indicated Frank or Gumbel copula as best-fitting, split neatly between northern and southern Europe (see Fig. 1 and Fig. 6), but when the upper 95 ${ }^{\text {th }}$ of the distribution was used, this value went down to only 60-67\%, scattered without a clear pattern around the continent (see Supplementary Fig. 17). For storm surge-river discharge pairs, the corresponding values are 76\% and 59-66\%. The contrast is even stronger for reanalysis data (Delft3D/ERA-Interim storm surges, ERA-Interim or EFAS precipitation and EFAS river discharges from) which have much less gaps in their time series compared to observations. At the same time, those modelled data represent the correlations between two marginal distributions poorly when the upper $95^{\text {th }}$ of the data series is used. In case of storm surge-precipitation pairs, the $\mathrm{R}^{2}$ between rank correlations from observations and modelled data is 0.61 for the whole marginal distributions and 0.18-0.27 for the upper $95^{\text {th }}$ (see Supplementary Fig. 16). For storm surge-river discharge pairs, the corresponding values are 0.38 and 0.19-0.31, respectively (see Supplementary Fig. 18).

The lower performance of the upper tail in recreating dependency can be largely attributed to lower performance of models regarding extreme events (Calafat et al., 2014). Indeed, rank correlations between modelled and observed $95^{\text {th }}$ percentiles of the margins are in the $0.34-0.36$ range, except between E-OBS and EFAS-Meteo (0.50), in contrast to 0.56-0.68 for the 
Hydrol. Earth Syst. Sci. Discuss., https://doi.org/10.5194/hess-2018-132

Manuscript under review for journal Hydrol. Earth Syst. Sci.

Discussion started: 19 April 2018

(c) Author(s) 2018. CC BY 4.0 License.

full marginal distributions. Importantly, return periods are also mostly lower when using the upper $95^{\text {th }}$ compared to the full distribution. For instance, at the Schelde estuary in Belgium, the location of a large compound flood in 1928 as well as many coastal and river floods, the return period of a joint event consisting of a 10-year storm surge and 10-year river discharge occurring at the same day was estimated at 52 years using the full marginal distributions, but at 4,000 and 25,000 years using the upper $95^{\text {th }}$ of one of the variables (with Delft3D/ERA-Interim and EFAS). If surge and discharge would be completely independent, the return period of such a compound event would be approximately 36,500 years. In general, the variation of return period between neighbouring coastal segments is higher when using the upper $95^{\text {th }}$ rather than the full margins.

In the presented analysis, there are two principal source of uncertainty. First is the data availability: the length of most series is only just enough for a univariate extreme value analysis ( $>30$ years), and some observational data series are even shorter (including EFAS covering only 24 years). The relative rarity of compound floods, as evidenced in the introduction and section 4.3, leads to reduced confidence in the resulting correlations. This fact also forbids an analysis of long-term changes to compound flood probability of occurrence. The second source of uncertainty is the choice of copula. Here, seven among the most popular copula types were used, but many more exist. Also, as a parametric model of dependency, it doesn't perfectly recreate the joint probability, and due to limited amount data the copula type might not be assigned correctly, leading to great differences in return periods, e. g. between Frank and Gumbel copulas. However, the relative spatial homogeneity and rather clear spatial patterns in distributions of copula types gives good confidence in the results. Upper tail dependence is most frequently observed, which means that high sea levels and high precipitation or river discharges are usually more correlated with each other than those variables at moderate or low intensity. This is particularly relevant in the Mediterranean region, where precipitation is concentrated in a smaller number of days - mostly less than 80 days during average year - compared to northern Europe, where it rains above 110 days on average (Klein Tank et al., 2002).

\subsection{Future research outlook}

Still, more work is needed in applying the joint distribution of flood-inducing events to flood hazard mapping. One important local factor omitted completely from the analysis are tides. A high tide can contribute significantly to a compound event (like in London in 1928), but tides are, barring for nonlinear effects on local sea level (Sterl et al., 2009; Rego and Li, 2010), an independent component. Additionally, they need to be analysed with a good temporal resolution, in contrast to 6- and 24-hourly data utilized here. After a pan-European analysis have been performed, local case studies should be carried out. Hydrodynamic modelling in good resolution would be required to assess the influence of joint occurrence of high water levels in both river and coastal side of an estuary (Couasnon, 2017). Such a model would have to take into account time-varying sea level (including tidal component), river discharge and wave heights. Detailed topography and bathymetry of the estuary would also be necessary. By modelling the dependency between hydrological events with copulas, the joint distribution could be sampled to provide a range of possible set-ups of simulations. That requires observational data from gauges located at the coast and in the river above the zone of influence of tides and surges on river water levels. An additional gauge on the river should be located in the area where the increase of water level caused by a compound event could be found, so that the model's validation can be performed. Further, the model should be run iteratively based on samples of the joint distribution, so that the 
Hydrol. Earth Syst. Sci. Discuss., https://doi.org/10.5194/hess-2018-132

Manuscript under review for journal Hydrol. Earth Syst. Sci.

Discussion started: 19 April 2018

(c) Author(s) 2018. CC BY 4.0 License.

local probability of flooding could be obtained that incorporates compound flood possibility. Finally, the analyses should be linked with historical events to fully to assess the circumstances that lead to compound flooding.

\section{Conclusions}

This paper analysed the joint occurrence of hydro-meteorological phenomena that have the potential to cause a compound

5 flood event. The analysis has identified areas with various patterns of dependency. Europe can be essentially divided in three regions. Southern Europe, with Portugal, Spain, Italy and Greece where the probability of joint occurrence of storm surge and precipitation is relatively high, and the intensity of the latter very large. Northern Europe, along the main corridor of winter storms that spans from Ireland and United Kingdom through the Netherlands, Denmark, southern Sweden and across the Baltic Sea. Here, dependency between surges and river discharges is higher than elsewhere, with large differences in flood potential between west-facing and east-facing coasts. The correlation between surges and precipitation can be very high, but there is also a lack of tail dependence, i.e. extreme events are not more likely to co-occur than more moderate events. This results in relatively high return periods for compound events. Finally, the far north of Europe (Iceland, Norway, Finland and northern Sweden) and Black Sea countries show very little potential for compound flood occurrence.

Performance of models in recreating observation dependencies is good in relation to precipitation, but much less so in case of river discharges. Simulations driven by the RCA4 regional climate model had mostly similar performance compared with the reanalysis, albeit the latter with a much coarser resolution. Therefore, there is potential for making relatively accurate future predictions of the dependency between surges and precipitation. River discharge estimations, on the other hand, still need improvements before such predictions can be confidently made.

The composite index of compound flood potential identified areas of most interest for further studying the topic. A few

20 European estuaries have experienced damaging compound floods in the past, and many more could be affected, especially in view of the projected rise in extreme sea levels (Vousdoukas et al., 2017) and river flood hazard (Alfieri et al., 2018). Those need to be analysed in detailed case studies with the use of hydrodynamic modelling.

Data availability. This work relied entirely on public data as inputs, which are available from the providers cited in section 2.1. Results of the work can be downloaded from an online repository (Paprotny et al., 2018c).

Competing interests. The authors declare that they have no conflict of interest.

Acknowledgements. This work was supported by European Union's Seventh Framework Programme under "Risk analysis of infrastructure networks in response to extreme weather" (RAIN) project, grant no. 608166. Additional support was provided by European Union's Horizon 2020 research and innovation programme under "Bridging the Gap for Innovations in Disaster resilience" (BRIGAID) project, grant no. 
Hydrol. Earth Syst. Sci. Discuss., https://doi.org/10.5194/hess-2018-132

Manuscript under review for journal Hydrol. Earth Syst. Sci.

Discussion started: 19 April 2018

(c) Author(s) 2018. CC BY 4.0 License.

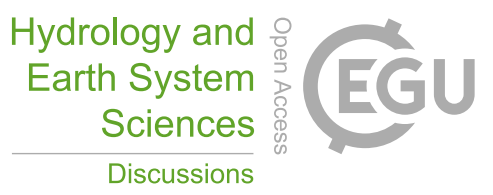

(c) (1)

700699. The authors would like to thank Lorenzo Alfieri, Lorenzo Mentaschi and Evangelos Voukouvalas at JRC for their help with data processing. 
Hydrol. Earth Syst. Sci. Discuss., https://doi.org/10.5194/hess-2018-132

Manuscript under review for journal Hydrol. Earth Syst. Sci.

Discussion started: 19 April 2018

\section{References}

Alfieri, L., Burek, P., Feyen, L., and Forzieri, G.: Global warming increases the frequency of river floods in Europe, Hydrology and Earth System Sciences, 19, 2247-2260, https://doi.org/10.5194/hess-19-2247-2015, 2015.

Alfieri, L., Feyen, L., Salamon, P., Thielen, J., Bianchi, A., Dottori, F., and Burek, P.: Modelling the socio-economic impact of river floods in Europe, Natural Hazards and Earth System Sciences, 16, 1401-1411, https://doi.org/10.5194/nhess-16-1401-2016, 2016.

Alfieri, L., Dottori, F., Betts, R., Salamon, P., and Feyen, L.: Multi-Model Projections of River Flood Risk in Europe under Global Warming, Climate, 6, 6, https://doi.org/10.3390/cli6010006, 2018.

Batstone, C., Lawless, M., Tawn, J., Horsburgh, K., Blackman, D., McMillan, A., Worth, D., Laeger, S., and Hunt, T.: A UK best-practice approach for extreme sea-level analysis along complex topographic coastlines, Ocean Engineering, 71, 28-39, https://doi.org/https://doi.org/10.1016/j.oceaneng.2013.02.003, 2013.

Bevacqua, E., Maraun, D., Hobæk Haff, I., Widmann, M., and Vrac, M.: Multivariate statistical modelling of compound events via pair-copula constructions: analysis of floods in Ravenna (Italy), Hydrology and Earth System Sciences, 21, 2701-2723, https://doi.org/10.5194/hess21-2701-2017, 2017.

Calafat, F. M., Avgoustoglou, E., Jordà, G., Flocas, H., Zodiatis, G., Tsimplis, M. N., and Kouroutzoglou, J.: The ability of a barotropic model to simulate sea level extremes of meteorological origin in the Mediterranean Sea, including those caused by explosive cyclones, Journal of Geophysical Research: Oceans, 119, 7840-7853, https://doi.org/10.1002/2014JC010360, 2014.

Couasnon, A. A. O.: Characterizing flood hazard at two spatial scales with the use of stochastic models: An application to the contiguous United States of America and the Houston Ship Channel, Master's thesis, TU Delft, 2017.

Dee, D. P., Uppala, S. M., Simmons, A. J., Berrisford, P., Poli, P., Kobayashi, S., Andrae, U., Balmaseda, M. A., Balsamo, G., Bauer, P., Bechtold, P., Beljaars, A. C. M., van de Berg, L., Bidlot, J., Bormann, N., Delsol, C., Dragani, R., Fuentes, M., Geer, A. J., Haimberger, L., Healy, S. B., Hersbach, H., Hólm, E. V., Isaksen, L., Kållberg, P., Köhler, M., Matricardi, M., McNally, A. P., Monge-Sanz, B. M., Morcrette, J.-J., Park, B.-K., Peubey, C., de Rosnay, P., Tavolato, C., Thépaut, J.-N., and Vitart, F.: The ERA-Interim reanalysis: configuration and performance of the data assimilation system, Quarterly Journal of the Royal Meteorological Society, 137, 553-597, https://doi.org/10.1002/qj.828, 2011.

Deltares: Delft3D-FLOW User Manual, https://oss.deltares.nl/documents/183920/185723/Delft3D-FLOW_User_Manual.pdf, 2014.

Dirección General de Protección Civil: Catálogo Nacional de Inundaciones Históricas, http://www.proteccioncivil.es/catalogo/naturales/cnih/ cnih2014/Presentacion.html, last accessed 13 January 2018, 2015.

Genest, C., Remillard, B., and Beaudoin, D.: Goodness-of-fit tests for copulas: A review and a power study, Insurance: Mathematics and Economics, 44, 199-213, https://doi.org/10.1016/j.insmatheco.2007.10.005, 2009.

30 Haylock, M. R., Hofstra, N., Klein Tank, A. M. G., Klok, E. J., Jones, P. D., and New, M.: A European daily high-resolution gridded data set of surface temperature and precipitation for 1950-2006, Journal of Geophysical Research: Atmospheres, 113, D20 119, https://doi.org/10.1029/2008JD010201, 2008.

Jacob, D., Petersen, J., Eggert, B., Alias, A., Christensen, O. B., Bouwer, L. M., Braun, A., Colette, A., Déqué, M., Georgievski, G., Georgopoulou, E., Gobiet, A., Menut, L., Nikulin, G., Haensler, A., Hempelmann, N., Jones, C., Keuler, K., Kovats, S., Kröner, N., Kotlarski, S., Kriegsmann, A., Martin, E., van Meijgaard, E., Moseley, C., Pfeifer, S., Preuschmann, S., Radermacher, C., Radtke, K., Rechid, D., Rounsevell, M., Samuelsson, P., Somot, S., Soussana, J.-F., Teichmann, C., Valentini, R., Vautard, R., Weber, B., and Yiou, P.: EURO- 
Hydrol. Earth Syst. Sci. Discuss., https://doi.org/10.5194/hess-2018-132

Manuscript under review for journal Hydrol. Earth Syst. Sci.

Discussion started: 19 April 2018

CORDEX: new high-resolution climate change projections for European impact research, Regional Environmental Change, 14, 563-578, https://doi.org/10.1007/s10113-013-0499-2, 2014.

Joe, H.: Dependence Modeling with Copulas, Chapman \& Hall/CRC, London, 2014.

Kew, S. F., Selten, F. M., Lenderink, G., and Hazeleger, W.: The simultaneous occurrence of surge and discharge extremes for the Rhine delta, Natural Hazards and Earth System Sciences, 13, 2017-2029, https://doi.org/10.5194/nhess-13-2017-2013, 2013.

Klein Tank, A. M. G., Wijngaard, J. B., Können, G. P., Böhm, R., Demarée, G., Gocheva, A., Mileta, M., Pashiardis, S., Hejkrlik, L., Kern-Hansen, C., Heino, R., Bessemoulin, P., Müller-Westermeier, G., Tzanakou, M., Szalai, S., Pálsdóttir, T., Fitzgerald, D., Rubin, S., Capaldo, M., Maugeri, M., Leitass, A., Bukantis, A., Aberfeld, R., van Engelen, A. F. V., Forland, E., Mietus, M., Coelho, F., Mares, C., Razuvaev, V., Nieplova, E., Cegnar, T., Antonio López, J., Dahlström, B., Moberg, A., Kirchhofer, W., Ceylan, A., Pachaliuk, O., Alexander, L. V., and Petrovic, P.: Daily dataset of 20th-century surface air temperature and precipitation series for the European Climate Assessment, International Journal of Climatology, 22, 1441-1453, https://doi.org/10.1002/joc.773, 2002.

Lehtonen, I., Ruosteenoja, K., and Jylhä, K.: Projected changes in European extreme precipitation indices on the basis of global and regional climate model ensembles, International Journal of Climatology, 34, 1208-1222, https://doi.org/10.1002/joc.3758, 2014.

Leonard, M., Westra, S., Phatak, A., Lambert, M., van den Hurk, B., McInnes, K., Risbey, J., Schuster, S., Jakob, D., and Stafford-Smith, M.: A compound event framework for understanding extreme impacts, Wiley Interdisciplinary Reviews: Climate Change, 5, 113-128, https://doi.org/10.1002/wcc.252, 2014.

Mentaschi, L., Vousdoukas, M. I., Voukouvalas, E., Dosio, A., and Feyen, L.: Global changes of extreme coastal wave energy fluxes triggered by intensified teleconnection patterns, Geophysical Research Letters, 44, 2416-2426, https://doi.org/10.1002/2016GL072488, 2017.

Meteo France : Pluies extrêmes en France métropolitaine, http://pluiesextremes.meteo.fr/france-metropole/-Tous-les-evenements-.html, last accessed 13 January 2018, 2017.

Moftakhari, H. R., Salvadori, G., AghaKouchak, A., Sanders, B. F., and Matthew, R. A.: Compounding effects of sea level rise and fluvial flooding, Proceedings of the National Academy of Sciences, 114, 9785-9790, https://doi.org/10.1073/pnas.1620325114, 2017.

Morales-Nápoles, O., Paprotny, D., Worm, D., Abspoel-Bukman, L., and Courage, W.: Characterization of Precipitation through Copulas and Expert Judgement for Risk Assessment of Infrastructure, ASCE-ASME Journal of Risk and Uncertainty in Engineering Systems, Part A: Civil Engineering, 3, 04017 012, https://doi.org/10.1061/AJRUA6.0000914, 2017.

Ntegeka, V. N., Salamon, P., Gomes, G., Sint, H., Lorini, V., Thielen del Pozo, J., and Zambrano, H.: EFAS-Meteo: A European daily high-resolution gridded meteorological data set for 1990 - 2011, Tech. rep., Joint Research Centre, https://doi.org/10.2788/51262, 2013.

Paprotny, D. and Morales-Nápoles, O.: Estimating extreme river discharges in Europe through a Bayesian network, Hydrology and Earth System Sciences, 21, 2615-2636, https://doi.org/10.5194/hess-21-2615-2017, 2017.

Paprotny, D., Morales-Nápoles, O., and Nikulin, G.: Extreme sea levels under present and future climate: a pan-European database, E3S Web of Conferences, 7, 02 001, https://doi.org/10.1051/e3sconf/20160702001, 2016.

Paprotny, D., Morales-Nápoles, O., and Jonkman, S. N.: HANZE: a pan-European database of exposure to natural hazards and damaging historical floods since 1870, Earth System Science Data, 10, 565-581, https://doi.org/10.5194/essd-10-565-2018, 2018a.

Paprotny, D., Sebastian, A., Morales-Nápoles, O., and Jonkman, S. N.: Trends in flood losses in Europe over the past 150 years, Nature Communications, 9, in print, https://arxiv.org/abs/1710.11044)/, 2018b.

Paprotny, D., Vousdoukas, M. I., and Morales-Nápoles, O.: Compound flood potential in Europe, Joint Research Centre, dataset, http: //data.jrc.ec.europa.eu/dataset/jrc-liscoast-10010, 2018c. 
Hydrol. Earth Syst. Sci. Discuss., https://doi.org/10.5194/hess-2018-132

Manuscript under review for journal Hydrol. Earth Syst. Sci.

Discussion started: 19 April 2018

(c) Author(s) 2018. CC BY 4.0 License.

Rego, J. L. and Li, C.: Nonlinear terms in storm surge predictions: Effect of tide and shelf geometry with case study from Hurricane Rita, Journal of Geophysical Research: Oceans, 115, C06 020, https://doi.org/10.1029/2009JC005285, 2010.

Salvadori, G. and Michele, C. D.: On the Use of Copulas in Hydrology: Theory and Practice, Journal of Hydrologic Engineering, 12, 369380, https://doi.org/10.1061/(ASCE)1084-0699(2007)12:4(369), 2007.

5 Schneider, C., Laizé, C. L. R., Acreman, M. C., and Flörke, M.: How will climate change modify river flow regimes in Europe?, Hydrology and Earth System Sciences, 17, 325-339, https://doi.org/10.5194/hess-17-325-2013, 2013.

Schölzel, C. and Friederichs, P.: Multivariate non-normally distributed random variables in climate research - introduction to the copula approach, Nonlinear Processes in Geophysics, 15, 761-772, https://doi.org/10.5194/npg-15-761-2008, 2008.

Scussolini, P., Aerts, J. C. J. H., Jongman, B., Bouwer, L. M., Winsemius, H. C., deÂ Moel, H., and Ward, P. J.: FLOPROS: an evolving global database

of flood protection standards, Natural Hazards and Earth System Sciences, 16, 1049-1061, https://doi.org/10.5194/nhess-16-1049-2016, 2016.

Sterl, A., van den Brink, H., de Vries, H., Haarsma, R., and van Meijgaard, E.: An ensemble study of extreme storm surge related water levels in the North Sea in a changing climate, Ocean Science, 5, 369-378, https://doi.org/10.5194/os-5-369-2009, 2009.

15 Strandberg, G., Bärring, L., Hansson, U., Jansson, C., Jones, C., Kjellström, E., Kolax, M., Kupiainen, M., Nikulin, G., Samuelsson, P., Ullerstig, A., and Wang, S.: CORDEX scenarios for Europe from the Rossby Centre regional climate model RCA4, Tech. rep., SMHI, Norrköping, Sweden, 2015.

Svensson, C. and Jones, D. A.: Dependence between extreme sea surge, river flow and precipitation in eastern Britain, International Journal of Climatology, 22, 1149-1168, https://doi.org/10.1002/joc.794, 2002.

Svensson, C. and Jones, D. A.: Dependence between sea surge, river flow and precipitation in south and west Britain, Hydrology and Earth System Sciences, 8, 973-992, https://doi.org/10.5194/hess-8-973-2004, 2004.

Tolman, H. L.: User manual and system documentation of WAVEWATCH-III version 2.22, Tech. rep., NOAA/NWS/NCEP/MMAB, 2002. van Oldenborgh, G. J., van der Wiel, K., Sebastian, A., Singh, R., Arrighi, J., Otto, F., Haustein, K., Li, S., Vecchi, G., and Cullen, H.: Attribution of extreme rainfall from Hurricane Harvey, August 2017, Environmental Research Letters, 12, 24 009, https://doi.org/10.1088/17489326/aa9ef2, 2017.

Vousdoukas, M. I., Voukouvalas, E., Annunziato, A., Giardino, A., and Feyen, L.: Projections of extreme storm surge levels along Europe, Climate Dynamics, 47, 3171-3190, https://doi.org/10.1007/s00382-016-3019-5, 2016.

Vousdoukas, M. I., Mentaschi, L., Voukouvalas, E., Verlaan, M., and Feyen, L.: Extreme sea levels on the rise along Europe's coasts, Earth's Future, 5, 304-323, https://doi.org/10.1002/2016EF000505, 2017.

Wahl, T., Jain, S., Bender, J., Meyers, S. D., and Luther, M. E.: Increasing risk of compound flooding from storm surge and rainfall for major US cities, Nature Climate Change, 5, 1093-1097, https://doi.org/10.1038/NCLIMATE2736, 2015.

Zhong, H., van Overloop, P.-J., van Gelder, P., and Rijcken, T.: Influence of a Storm Surge Barrier's Operation on the Flood Frequency in the Rhine Delta Area, Water, 4, 474-493, https://doi.org/10.3390/w4020474, 2012. 
Hydrol. Earth Syst. Sci. Discuss., https://doi.org/10.5194/hess-2018-132

Manuscript under review for journal Hydrol. Earth Syst. Sci.

Discussion started: 19 April 2018
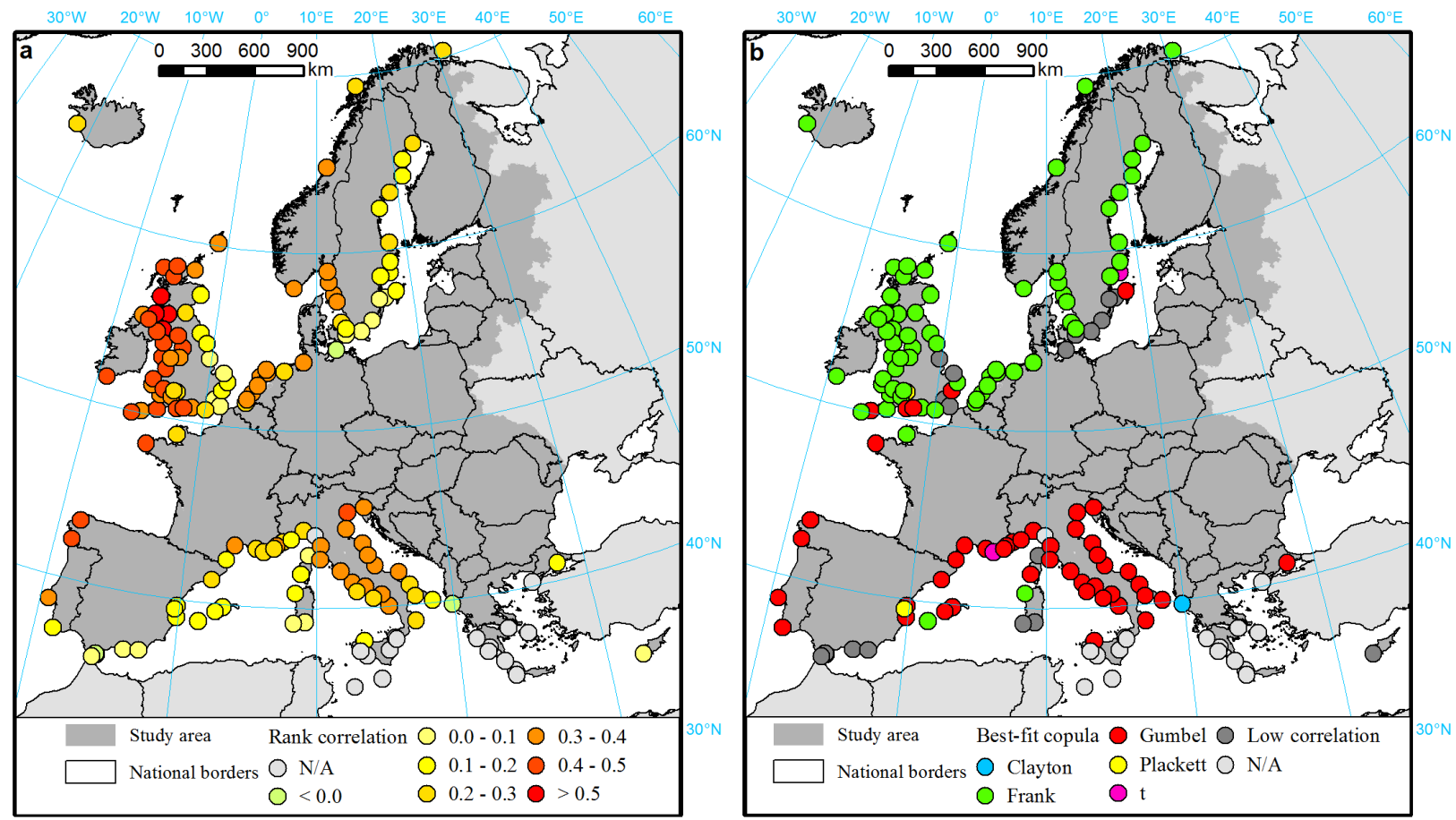

Figure 1. (a) rank correlation between observed daily storm surge and precipitation; (b) best-fitting copula type for dependency between observed daily storm surge and precipitation. 
Hydrol. Earth Syst. Sci. Discuss., https://doi.org/10.5194/hess-2018-132

Manuscript under review for journal Hydrol. Earth Syst. Sci.

Discussion started: 19 April 2018

\section{(c) (1)}
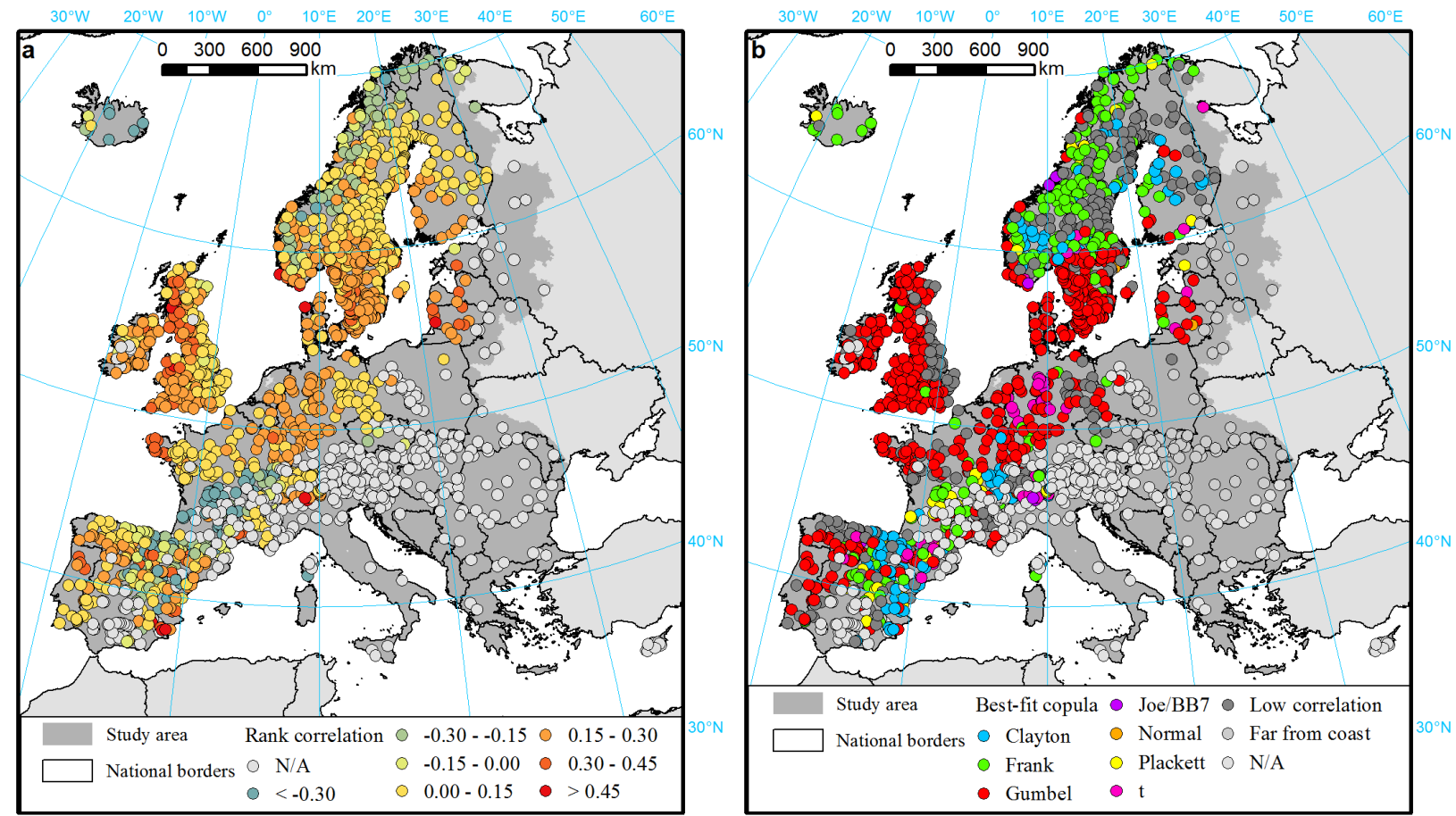

Figure 2. (a) rank correlation between observed daily storm surge and river discharge (river gauges compared with the closest tide gauge); (b) best-fitting copula type for dependency between observed daily storm surge and river discharge (river gauges compared with the closest tide gauge). 
Hydrol. Earth Syst. Sci. Discuss., https://doi.org/10.5194/hess-2018-132 Manuscript under review for journal Hydrol. Earth Syst. Sci.

Discussion started: 19 April 2018

(c) Author(s) 2018. CC BY 4.0 License.

\section{(c) (i)}

\section{Hydrology and Earth System Sciences \\ Discussions}
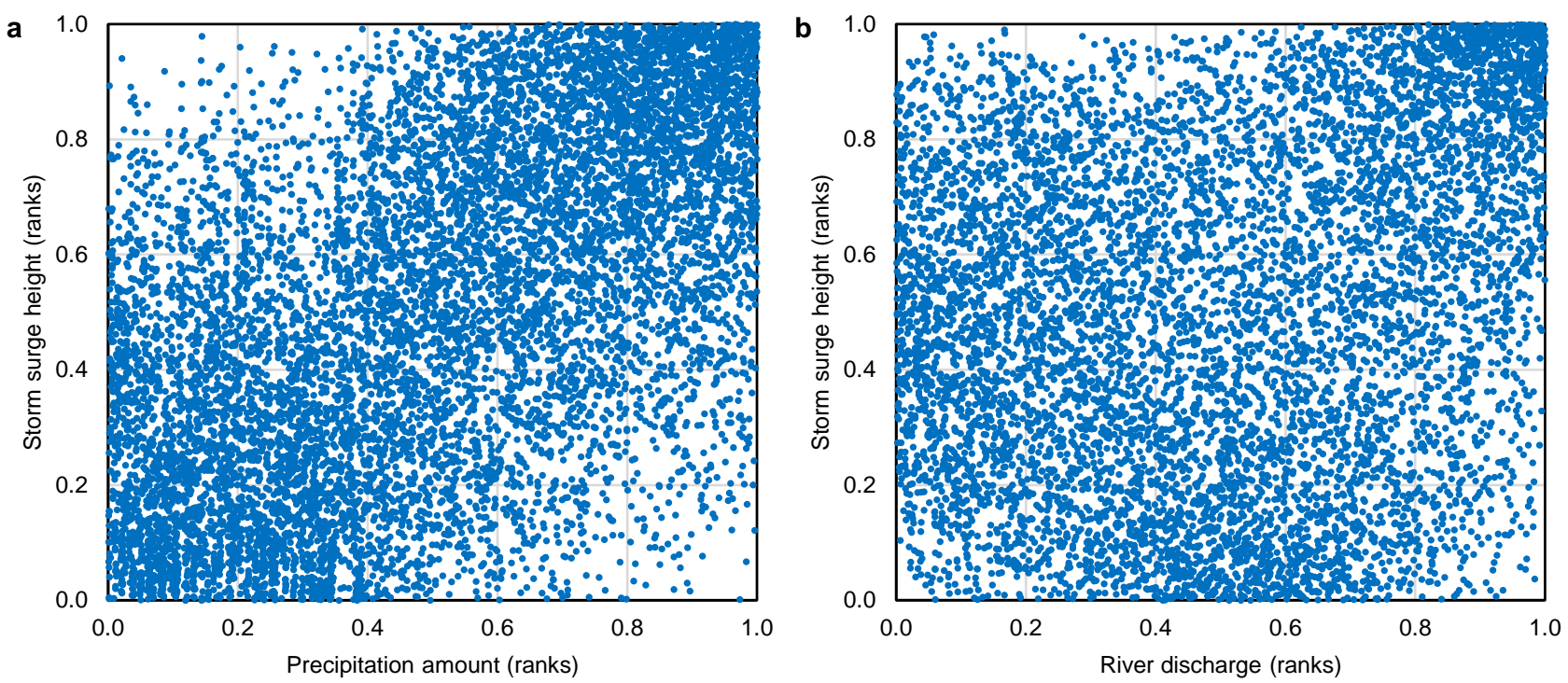

Figure 3. Examples of highly correlated storm surges and precipitation (a) or river discharge (b). In the left example, station Millport in Scotland shows Frank copula-type dependency, while in the other example, surges from Tredge, southern Norway, exhibit Gumbel copulatype dependency with discharges at river station Haugland. 
Hydrol. Earth Syst. Sci. Discuss., https://doi.org/10.5194/hess-2018-132

Manuscript under review for journal Hydrol. Earth Syst. Sci.

Discussion started: 19 April 2018
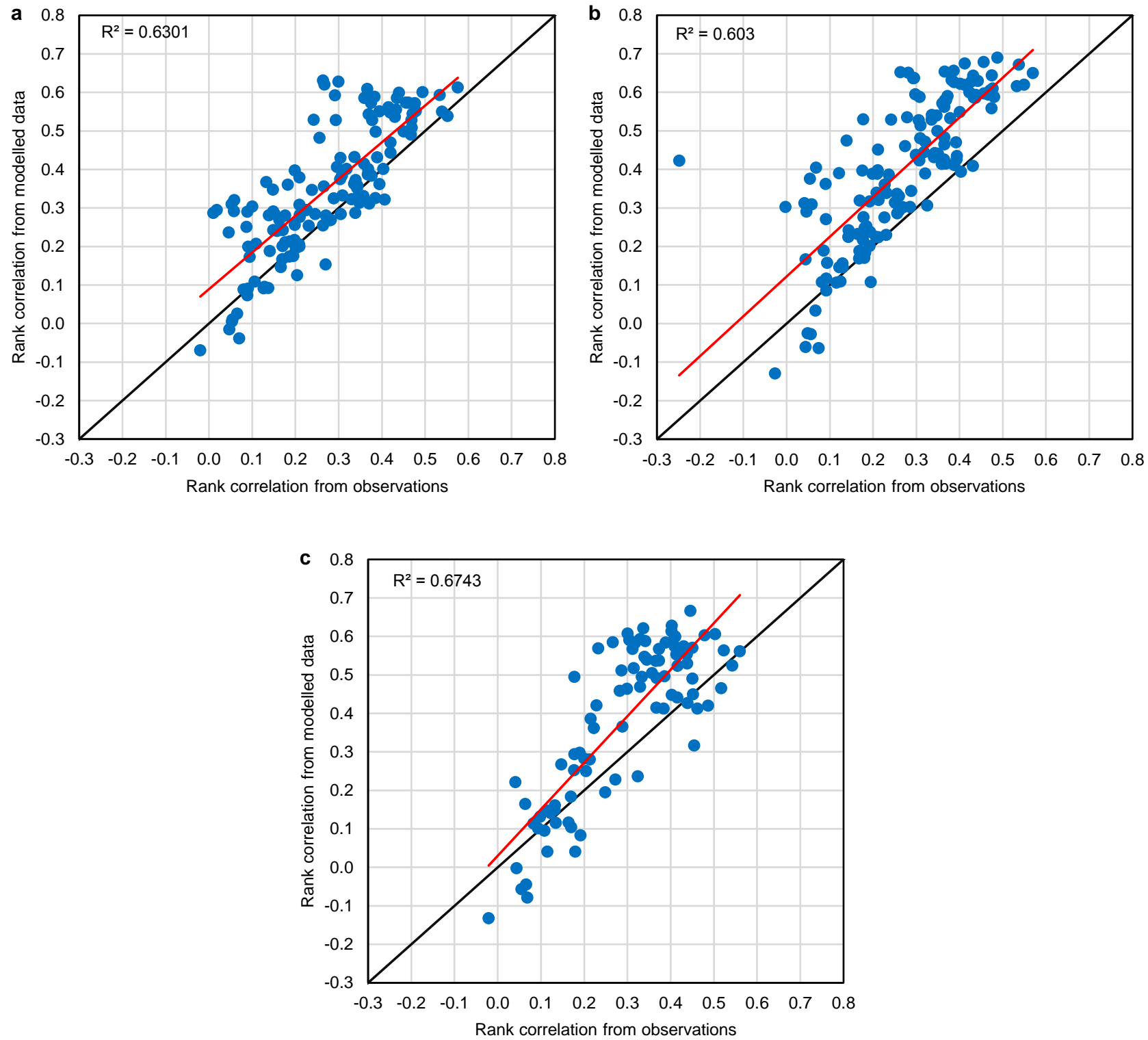

Figure 4. Comparison of rank correlations between daily storm surges and precipitation. (a) Delft3D/ERA-Interim + EFAS-Meteo; (b) Delft3D/ERA-Interim + ERA-Interim; (c) Delft3D/CORDEX + CORDEX. 
Hydrol. Earth Syst. Sci. Discuss., https://doi.org/10.5194/hess-2018-132 Manuscript under review for journal Hydrol. Earth Syst. Sci.

Discussion started: 19 April 2018

(c) Author(s) 2018. CC BY 4.0 License.
Hydrology and Earth System Sciences

Discussions (C) (1)
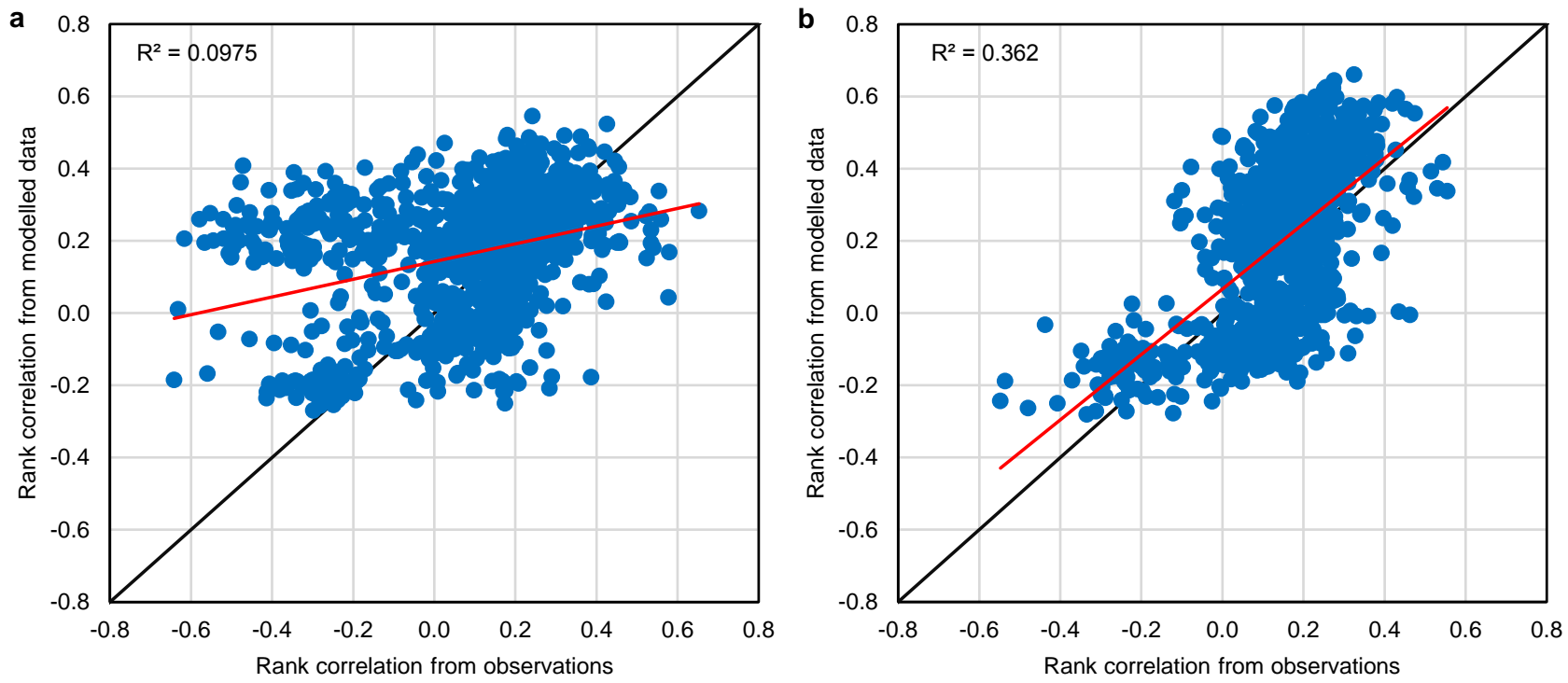

Figure 5. Comparison of rank correlations between daily storm surges and river discharge. (a) Delft3D/ERA-Interim + EFAS/EFAS-Meteo; (b) Delft3D/CORDEX + EFAS/CORDEX. 
Hydrol. Earth Syst. Sci. Discuss., https://doi.org/10.5194/hess-2018-132

Manuscript under review for journal Hydrol. Earth Syst. Sci.

Discussion started: 19 April 2018

(c) Author(s) 2018. CC BY 4.0 License.

a

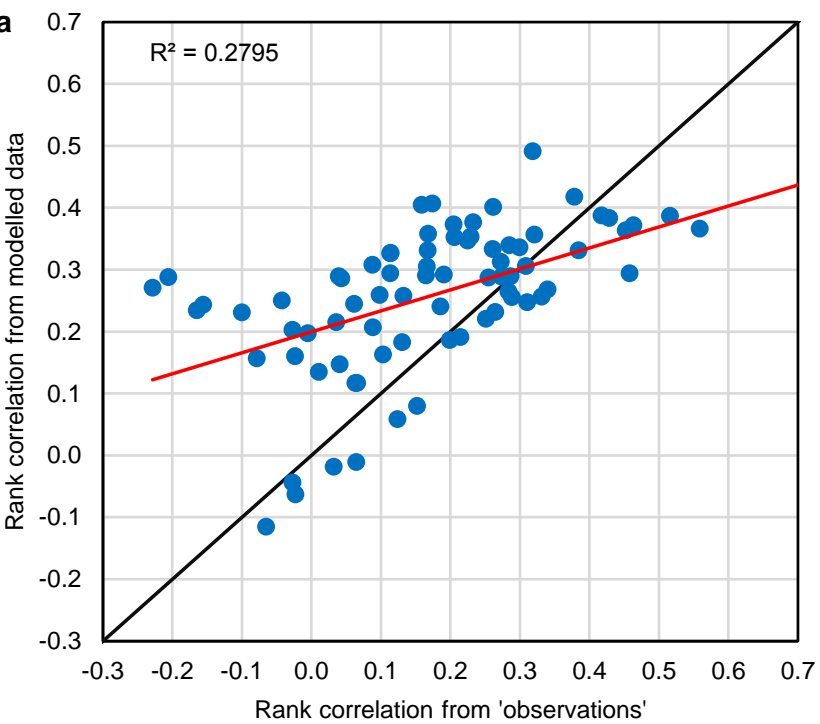

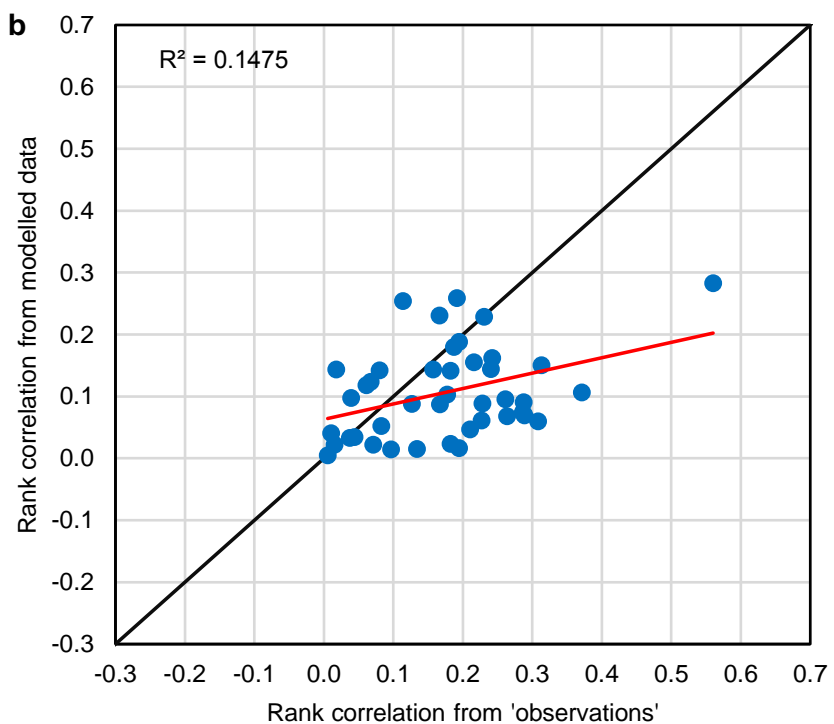

Figure 6. Comparison of rank correlations between modelled and 'observed' (tide gauges + EFAS/EFAS-Meteo) daily storm surge and river discharge for closest river with catchment area of at least $500 \mathrm{~km}^{2}$. (a) Delft3D/ERA-Interim + EFAS/EFAS-Meteo; (b) Delft3D/CORDEX + EFAS/CORDEX. 
Hydrol. Earth Syst. Sci. Discuss., https://doi.org/10.5194/hess-2018-132

Manuscript under review for journal Hydrol. Earth Syst. Sci.

Discussion started: 19 April 2018
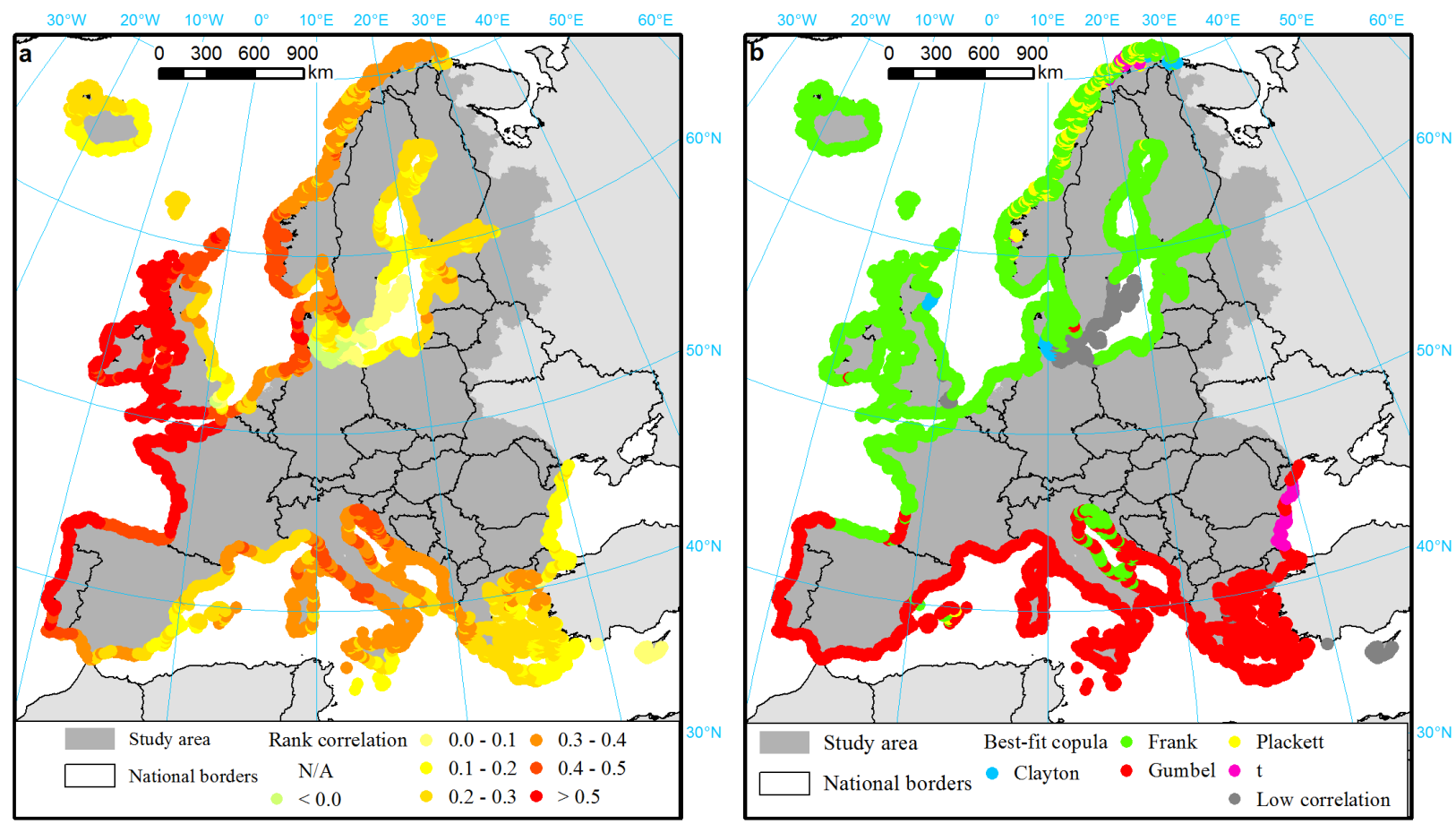

Figure 7. (a) rank correlation between modelled daily storm surge (Delft3D/ERA-Interim) and precipitation (EFAS-Meteo); (b) best-fitting copula type for dependency between modelled daily storm surge and precipitation. 
Hydrol. Earth Syst. Sci. Discuss., https://doi.org/10.5194/hess-2018-132

Manuscript under review for journal Hydrol. Earth Syst. Sci.

Discussion started: 19 April 2018

(c) Author(s) 2018. CC BY 4.0 License.
Hydrology and

Earth System

Sciences

Discussions

(c) (1)
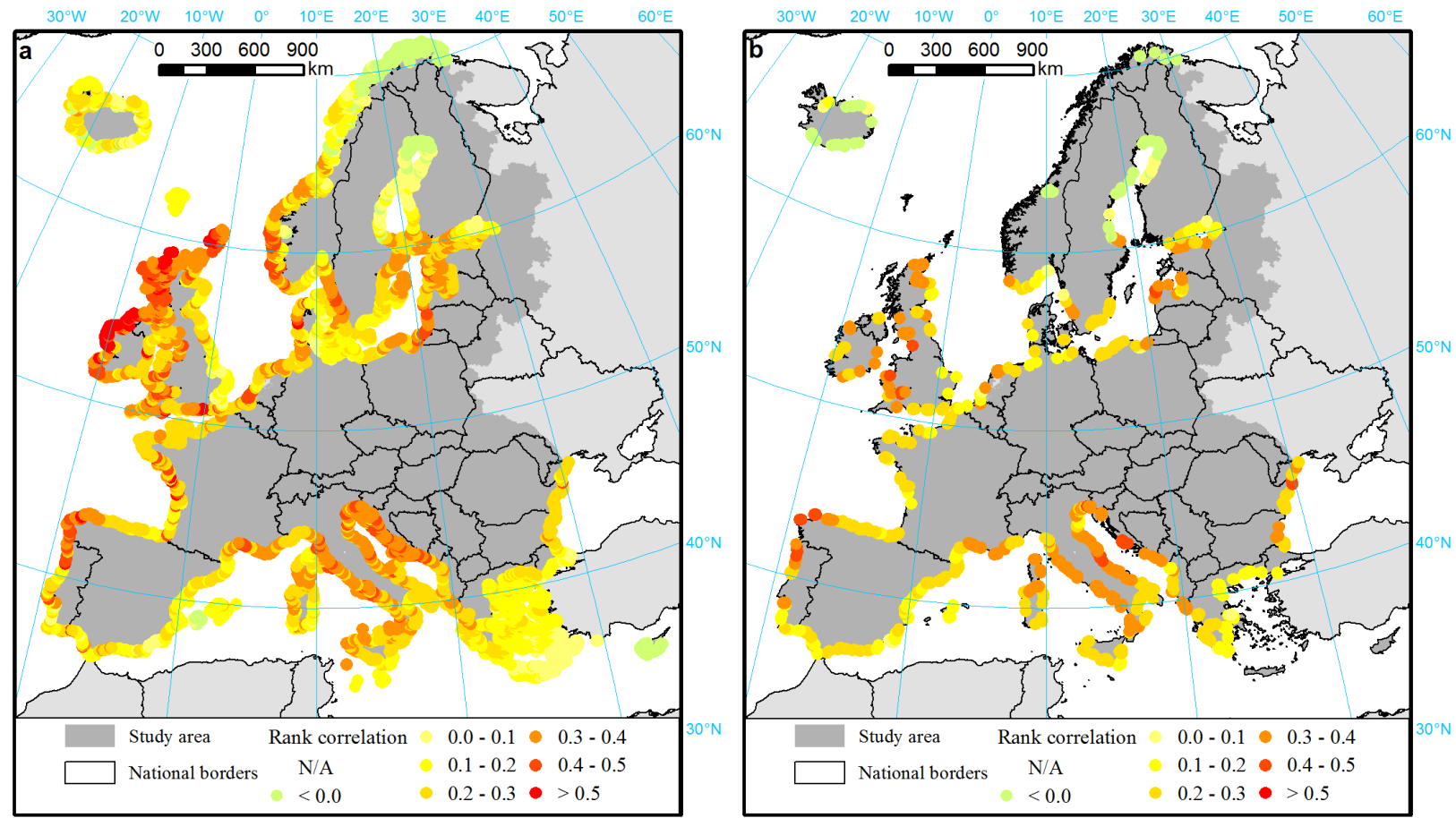

Figure 8. Rank correlation between modelled daily storm surge (Delft3D/ERA-Interim) and river discharge (EFAS/EFAS-Meteo), for (a) any closest river and (b) for closest river with catchment area of at least $500 \mathrm{~km}^{2}$. For rank correlation between observed surge and EFAS/EFASMeteo-modelled river discharges in outlined circles see Supplementary Fig. 11). 
Hydrol. Earth Syst. Sci. Discuss., https://doi.org/10.5194/hess-2018-132

Manuscript under review for journal Hydrol. Earth Syst. Sci.

Discussion started: 19 April 2018

(c) Author(s) 2018. CC BY 4.0 License.
Hydrology and

Earth System

Sciences

Discussions

(c) (1)
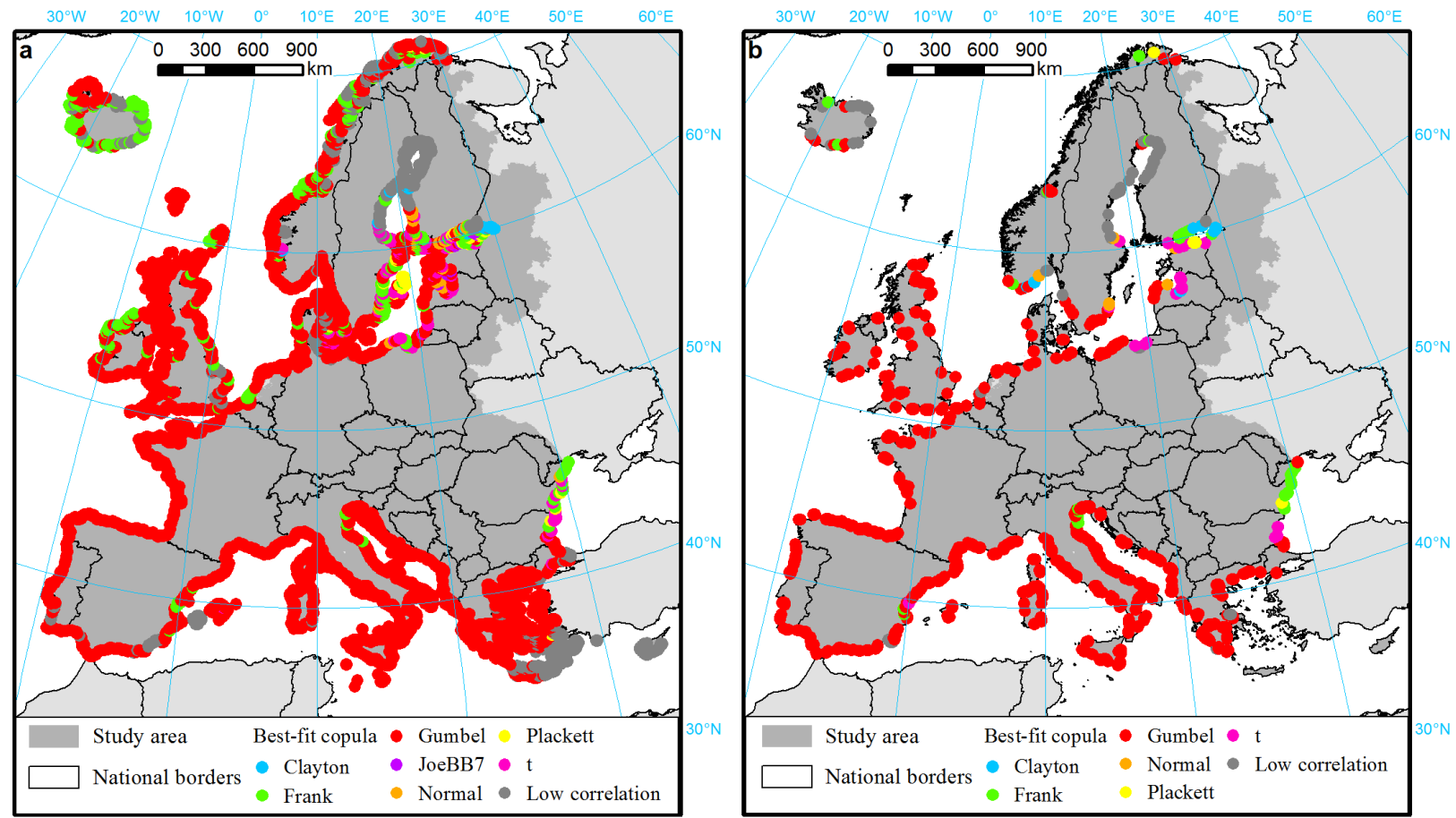

Figure 9. Best-fitting copula type for dependency between modelled daily storm surge (Delft3D/ERA-Interim) and river discharge (EFAS/EFAS-Meteo), for (a) any closest river and (b) for closest river with catchment area of at least $500 \mathrm{~km}^{2}$. For best-fitting copila types for observed surge and EFAS/EFAS-Meteo-modelled river discharges see Supplementary Fig. 12. 
Hydrol. Earth Syst. Sci. Discuss., https://doi.org/10.5194/hess-2018-132

Manuscript under review for journal Hydrol. Earth Syst. Sci.

Discussion started: 19 April 2018

(c) Author(s) 2018. CC BY 4.0 License.
Hydrology and

Earth System

Sciences

Discussions

(c) (1)
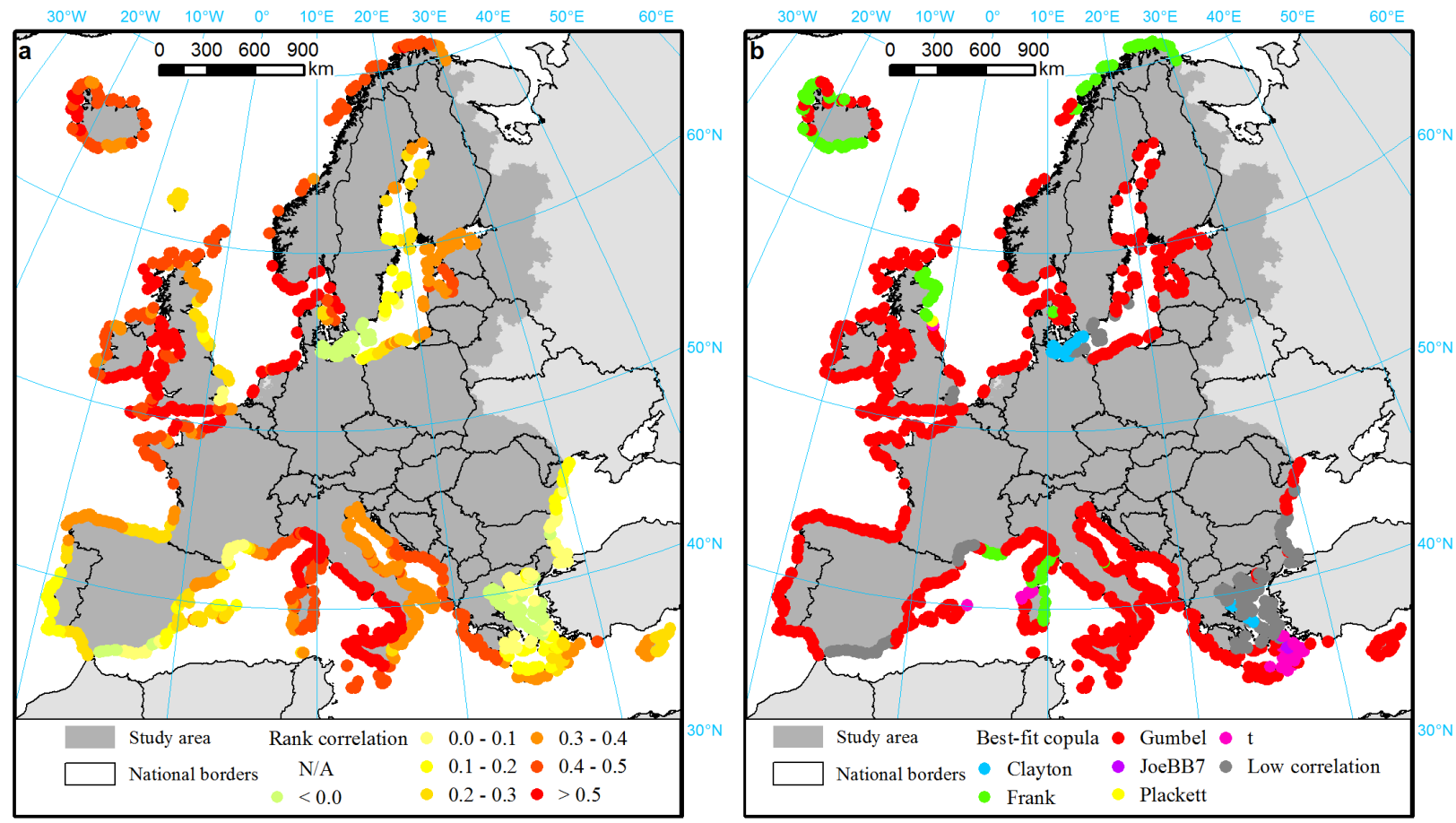

Figure 10. (a) rank correlation between modelled daily storm surge and significant wave height (Delft3D/ERA-Interim + WW3/ERAInterim). Rank correlation between observed surge and modelled wave height in outlined circles; (b) best-fitting copula type for dependency between daily storm surge and significant wave height. 
Hydrol. Earth Syst. Sci. Discuss., https://doi.org/10.5194/hess-2018-132

Manuscript under review for journal Hydrol. Earth Syst. Sci.

Discussion started: 19 April 2018
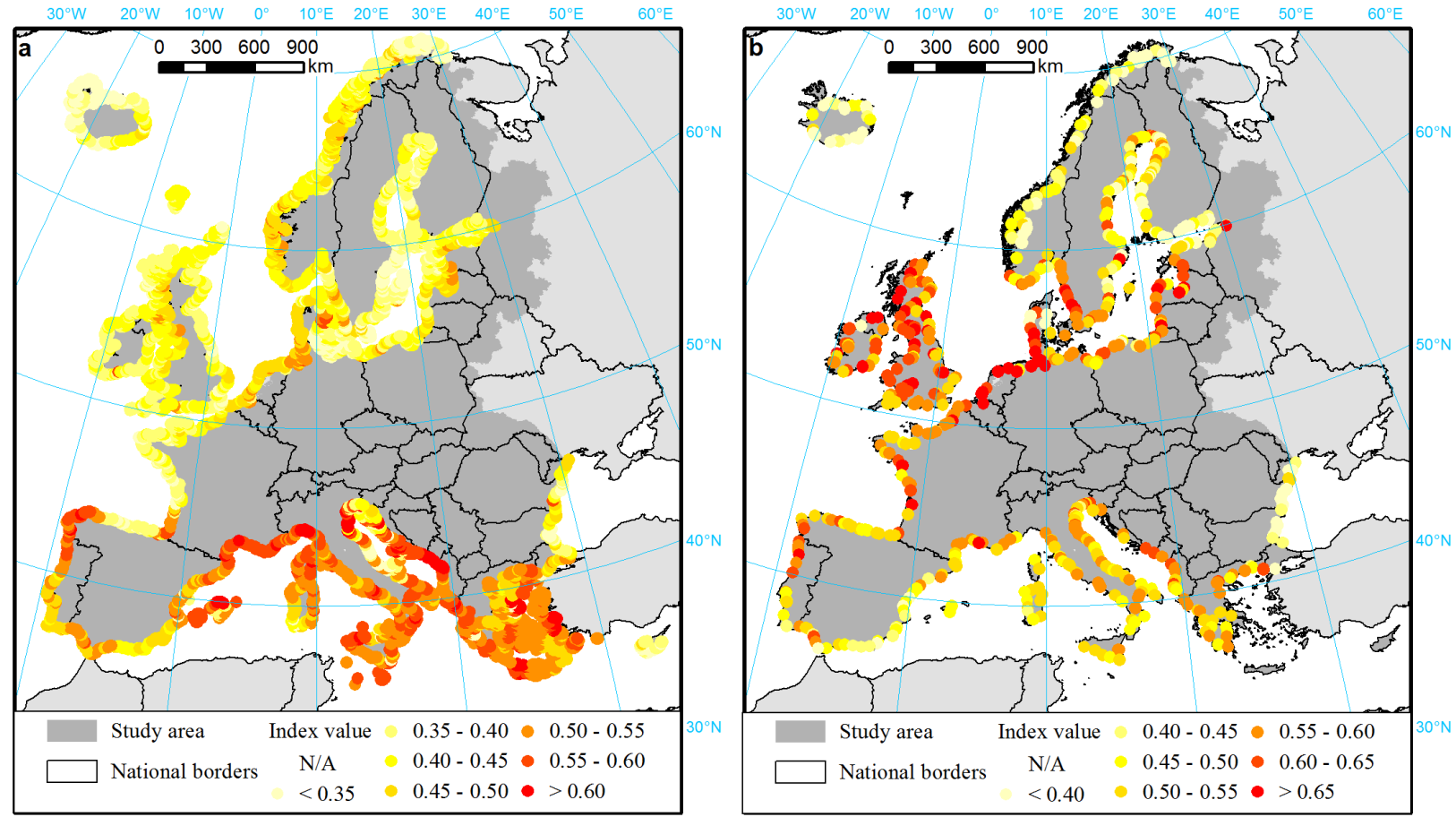

Figure 11. Compound Flood Potential Index for (a) flash flood-storm surge co-occurrence and (b) river flood-storm surge co-occurrence, for the 1990-2013 period. Note that the index for river floods was computed for rivers with catchment area of at least $500 \mathrm{~km}^{2}$, with the locations being actual estuaries, rather than Delft3D grid cells as shown in previous figures. 
Hydrol. Earth Syst. Sci. Discuss., https://doi.org/10.5194/hess-2018-132

Manuscript under review for journal Hydrol. Earth Syst. Sci.

Discussion started: 19 April 2018

\section{(c) (1)}
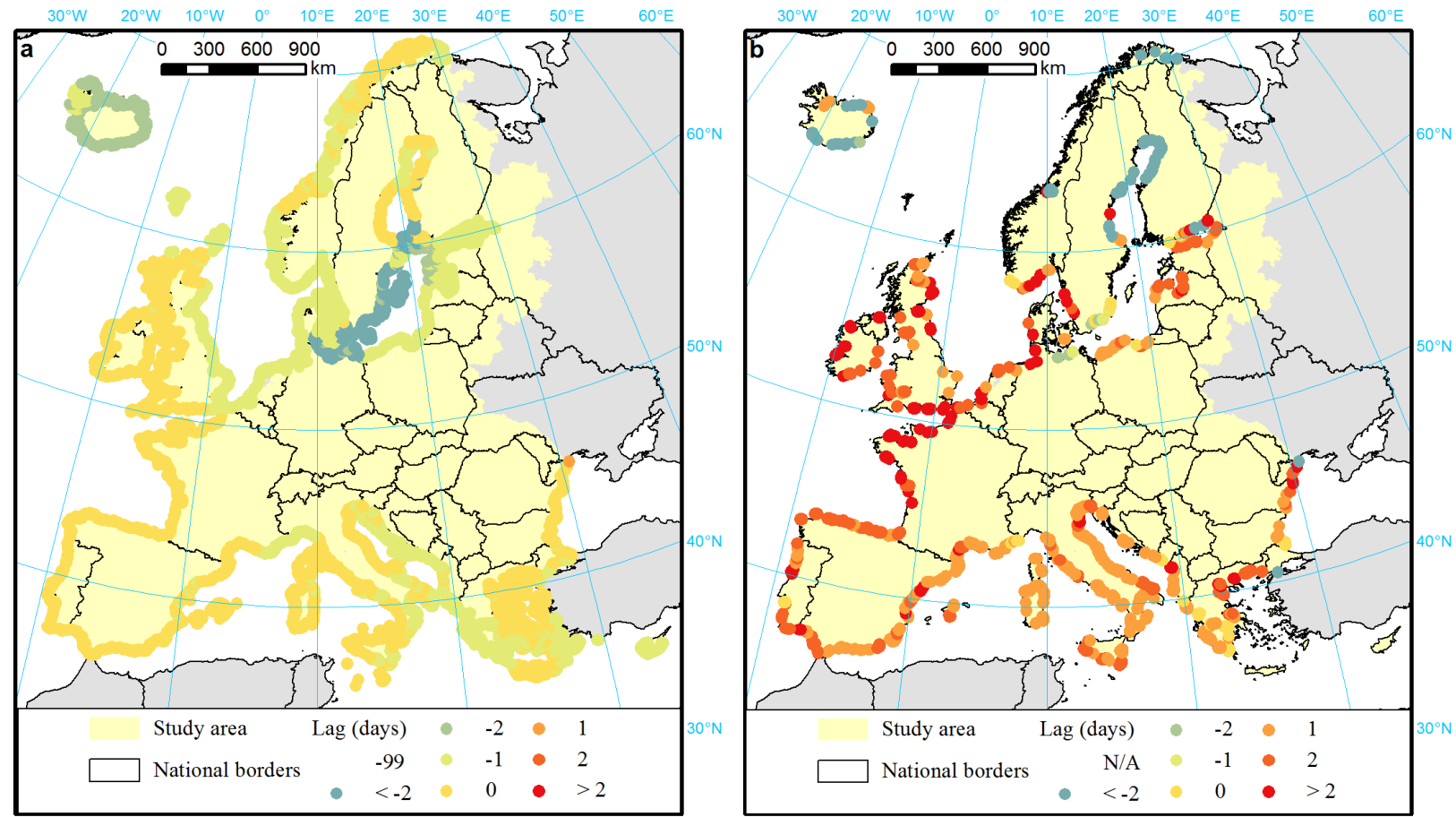

Figure 12. Lag between storm surge height (Delft3D/ERA-Interim) and (a) daily precipitation from EFAS-Meteo or (b) daily river discharge from EFAS for catchments with an area of at least $500 \mathrm{~km}^{2}$, that has the highest correlation with storm surge height series. 
Hydrol. Earth Syst. Sci. Discuss., https://doi.org/10.5194/hess-2018-132

Manuscript under review for journal Hydrol. Earth Syst. Sci.

Discussion started: 19 April 2018

(c) Author(s) 2018. CC BY 4.0 License.

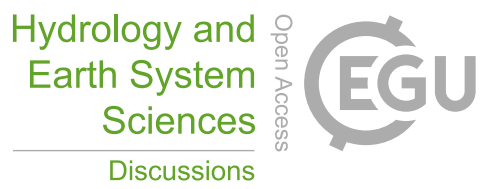

(c) (1)

Table 1. Summary of data collected for the study, by variable, input climate forcing, temporal resolution and timespan. See text for details and sources of datasets.

\begin{tabular}{lcccc}
\hline $\begin{array}{l}\text { Climate forcing }> \\
\text { Variable v }\end{array}$ & Observations & EFAS-Meteo & ERA-Interim & EURO-CORDEX (RCA4) \\
\hline River discharges & daily 1950-2013 & daily 1990-2013 & - & daily 1970-2005 \\
Storm surges & hourly 1970-2014 & - & 6-hourly 1979-2014 & 6-hourly 1970-2005 \\
Precipitation & daily 1950-2017 & daily 1990-2013 & 3-hourly 1979-2016 & 6-hourly 1970-2005 \\
Wave height & subdaily 1989-2013 & - & 3-hourly 1980-2012 & - \\
\hline
\end{tabular}


Hydrol. Earth Syst. Sci. Discuss., https://doi.org/10.5194/hess-2018-132

Table 2. A summary of copulas used in the analysis. Based on Joe (2014).

\begin{tabular}{|c|c|c|}
\hline Copula & CDF for copula $C$ & Tail dependence \\
\hline Gaussian & $C(u, v ; \rho)=\Phi_{\rho}\left(\Phi^{-1}(u), \Phi^{-1}(v)\right), \rho \in[-1,1]$ & No \\
\hline Gumbel & $C(u, v ; \delta)=\exp \left(-\left([-\log (u)]^{\delta}+[-\log (v)]^{\delta}\right)^{1 / \delta}\right), \delta \geq 1$ & Upper \\
\hline Clayton & $C(u, v ; \alpha)=\left(u^{-\alpha}+v^{-\alpha}-1\right)^{-\alpha}, \alpha \in[-1, \infty)$ & Lower \\
\hline Frank & $C(u, v ; \theta)=-\theta^{-1} \log \left(\frac{1-e^{-\theta}-\left(1-e^{-\theta u}\right)\left(1-e^{-\theta v}\right.}{1-e^{-\theta}}\right), \theta \in(-\infty, \infty)$ & No \\
\hline$t$ & $C(u, v ; P ; f)=\int_{-\infty}^{t_{f}^{-1}(u)} \int_{-\infty}^{t_{f}^{-1}(v)} \frac{\Gamma\left(\frac{f+2}{2}\right.}{\Gamma\left(\frac{f}{2} \sqrt{(\pi f)^{2}|P|}\right.}\left(1+\frac{\mathbf{x}^{\prime} P^{-1} \mathbf{x}}{f}\right)^{-\frac{v+2}{2}} 2 \mathbf{x}$ & Upper and lowe \\
\hline Plackett & $C(u, v ; \vartheta)=\frac{1}{2} \eta^{-1}\left(1+\eta(u+v)-\left[(1+\eta(u+v))^{2}-4 \vartheta \eta u v\right]^{\frac{1}{2}}\right), \vartheta \geq 0$ & No \\
\hline Joe-Clayton (BB7) & $C(u, v ; \kappa, \beta)=1-\left(1-\left[\left(1-\bar{u}^{\kappa}\right)^{-\beta}-\left(1-\bar{v}^{\kappa}\right)^{-\beta}-1\right]^{-\frac{1}{\kappa}}\right)^{\frac{1}{\beta}}, \kappa \geq 1, \beta>0$ & Upper and lowe \\
\hline
\end{tabular}

Symbols: $u, v \in[0,1], \Phi$ is the bivariate Gaussian cumulative distribution with Pearson's correlation coefficient $\rho, \eta=\vartheta-1, t_{f}^{-1}$ denotes the quantile function of a standard univariate $t_{f}$ distribution, $f$ are the degrees of freedom, $\mathbf{x}$ is a random vector, and the remaining symbols are copula-specific parameters. 
Hydrol. Earth Syst. Sci. Discuss., https://doi.org/10.5194/hess-2018-132

Manuscript under review for journal Hydrol. Earth Syst. Sci.

Discussion started: 19 April 2018

(c) Author(s) 2018. CC BY 4.0 License.
Hydrology and

Earth System

Sciences

Discussions

(c) (i)

Table 3. Compound flood events, defined by occurrence on the same day of a storm surge with at least 10-year return period and extreme precipitation or river discharge also with at least 10-year return period, identified in reanalysis data (Delft3D/ERA-Interim surge with EFAS/EFAS-Meteo discharge, EFAS-Meteo precipitation or ERA-Interim precipitation). Historical records of losses from HANZE database (Paprotny et al., 2018a), Meteo France (2017) and Dirección General de Protección Civil (2015).

\begin{tabular}{|c|c|c|c|c|}
\hline No. & Type & Date & Location & Historical records of losses \\
\hline 1 & Surge-river discharge & $07-12-2000$ & $\begin{array}{l}\text { Minho river, Portugal/Spain; Duero } \\
\text { river (Portugal) }\end{array}$ & $\begin{array}{l}\text { Flash flood in Spain recorded further } \\
\text { upstream (ca. } 600 \text { persons affected) }\end{array}$ \\
\hline 2 & Surge-river discharge & $27-12-2002$ & Duero river, Portugal & $\begin{array}{l}\text { Flash floods recorded in several regions } \\
\text { (ca. } 100 \text { persons affected) }\end{array}$ \\
\hline 3 & Surge-river discharge & 24-12-2009 & Guadalate river, Spain & $\begin{array}{l}\text { River floods in recorded further up- } \\
\text { stream (ca. } 600 \text { persons affected) }\end{array}$ \\
\hline 4 & Surge-precipitation & 22-01-1981 & Central Greece region, Greece & No records \\
\hline 5 & Surge-precipitation & 31-01-1986 & Venezia province, Italy & $\begin{array}{l}\text { Large compound flood, } 5 \text { fatalities, 50- } \\
70 \text { mln euro damages in } 2011 \text { prices }\end{array}$ \\
\hline 6 & Surge-precipitation & $15-10-1987$ & $\begin{array}{l}\text { Galicia region, Spain; Loire-Atlantique, } \\
\text { Vendee and Morbihan departments, } \\
\text { France }\end{array}$ & $\begin{array}{l}\text { Some houses damaged in Galicia (no } \\
\text { quantitative data) }\end{array}$ \\
\hline 7 & Surge-precipitation & $22-12-2000$ & Andalusia, Spain & $\begin{array}{l}\text { Some houses damaged (no quantitative } \\
\text { data) }\end{array}$ \\
\hline 8 & Surge-precipitation & 25-01-2009 & $\begin{array}{l}\text { Thessaly and Western Macedonia re- } \\
\text { gions, Greece }\end{array}$ & No records \\
\hline 9 & Surge-precipitation & 06-01-2012 & Eastern Macedonia region, Greece & No records \\
\hline 10 & Surge-precipitation & $10-09-2012$ & Northern Iceland & $\begin{array}{l}\text { No records (very scarcely populated } \\
\text { area) }\end{array}$ \\
\hline 11 & Surge-precipitation & $24-12-2013$ & $\begin{array}{l}\text { Charente-Maritime, Loire-Atlantique, } \\
\text { and Vendee departments, France }\end{array}$ & $\begin{array}{l}\text { Windstorm and floods recorded (no data } \\
\text { on losses) }\end{array}$ \\
\hline
\end{tabular}


Hydrol. Earth Syst. Sci. Discuss., https://doi.org/10.5194/hess-2018-132

Manuscript under review for journal Hydrol. Earth Syst. Sci.

Discussion started: 19 April 2018

(c) Author(s) 2018. CC BY 4.0 License.

Table 4. Top 12 river estuaries in Europe ranked by compound flood potential. Return period is of a 10-year surge and 10-year river discharge occurring on the same day. Past damaging floods from HANZE database (Paprotny et al., 2018a).

\begin{tabular}{|c|c|c|c|c|c|c|c|c|c|c|}
\hline \multirow[t]{2}{*}{ Rank } & \multirow[t]{2}{*}{ River } & \multirow[t]{2}{*}{ City/country } & \multirow{2}{*}{$\begin{array}{l}\text { Catch- } \\
\text { ment } \\
\text { area } \\
\left(\mathrm{km}^{2}\right)\end{array}$} & \multirow{2}{*}{$\begin{array}{l}\text { Return } \\
\text { period } \\
\text { (years) }\end{array}$} & \multirow{2}{*}{$\begin{array}{l}10 \text {-year } \\
\text { storm } \\
\text { surge } \\
\text { (m) }\end{array}$} & \multirow{2}{*}{$\begin{array}{l}10 \text {-year } \\
\text { dis- } \\
\text { charge } \\
\left(\mathrm{m}^{3} \mathrm{~s}^{-1}\right)\end{array}$} & \multicolumn{4}{|c|}{$\begin{array}{l}\text { Past damaging floods in the region of } \\
\text { the estuary by type }\end{array}$} \\
\hline & & & & & & & Coastal & River & $\begin{array}{l}\text { Com- } \\
\text { pound }\end{array}$ & Flash \\
\hline 1 & Weser & $\begin{array}{l}\text { Bremerhaven, } \\
\text { Germany }\end{array}$ & 44,700 & 182 & 1.86 & 2128 & 1973, 1976 & $\begin{array}{l}1909,1956, \\
1998^{*}\end{array}$ & & \\
\hline 2 & Scheldt & $\begin{array}{l}\text { Antwerp, Bel- } \\
\text { gium }\end{array}$ & 19,400 & 52 & 1.57 & 1179 & $\begin{array}{l}1906,1953, \\
1976\end{array}$ & & 1928 & 1998 \\
\hline 3 & Meuse & $\begin{array}{l}\text { Dordrecht, } \\
\text { Netherlands }\end{array}$ & 34,700 & 129 & 1.29 & 2823 & $1953^{* *}$ & $\begin{array}{l}1926,1993, \\
1995\end{array}$ & & 1998 \\
\hline 4 & Elbe & $\begin{array}{l}\text { Hamburg, } \\
\text { Germany }\end{array}$ & 138,300 & 2632 & 2.23 & 4356 & $\begin{array}{l}1962,1973, \\
1976\end{array}$ & $\begin{array}{l}1888,2002, \\
2016\end{array}$ & & \\
\hline 5 & Rhine & $\begin{array}{l}\text { Rotterdam, } \\
\text { Netherlands }\end{array}$ & 164,100 & 1639 & 1.28 & 11,082 & $1953^{* *}$ & $\begin{array}{l}1926,1993, \\
1995\end{array}$ & & 1998 \\
\hline 6 & Garonne & $\begin{array}{l}\text { Bordeaux, } \\
\text { France }\end{array}$ & 80,800 & 217 & 0.78 & 5248 & 2010 & 1930,1981 & & \\
\hline 7 & Eden & Carlisle, UK & 2300 & 71 & 1.35 & 635 & 1977 & $\begin{array}{l}2005^{*} \\
2012,2015\end{array}$ & & $\begin{array}{l}1953, \\
2009 *\end{array}$ \\
\hline 8 & Loire & $\begin{array}{l}\text { Saint- } \\
\text { Nazaire, } \\
\text { France }\end{array}$ & 116,200 & 382 & 0.81 & 4679 & 1924,1937 & $\begin{array}{l}1910,1995, \\
2001\end{array}$ & & \\
\hline 9 & Lune & $\begin{array}{l}\text { Lancaster, } \\
\text { UK }\end{array}$ & 900 & 63 & 1.33 & 303 & 1927, 1977 & $\begin{array}{l}1903,2012, \\
2015\end{array}$ & & $2009 *$ \\
\hline 10 & Ouse & Hull, UK & 10,600 & 109 & 0.81 & 1215 & $\begin{array}{l}1921,1953, \\
1976,1978, \\
2013\end{array}$ & $\begin{array}{l}1947,1982, \\
1999,2007, \\
2012\end{array}$ & 1954 & 1910 \\
\hline 11 & Wye & $\begin{array}{l}\text { Chepstow, } \\
\text { UK }\end{array}$ & 3800 & 65 & 0.9 & 651 & 2014 & $\begin{array}{l}1998 \\
2000 *\end{array}$ & & \\
\hline 12 & Severn & $\begin{array}{l}\text { Gloucester, } \\
\text { UK }\end{array}$ & 10,700 & 104 & 0.9 & 880 & $2014^{* * *}$ & $\begin{array}{l}1947,1982, \\
2007,2012, \\
2013,2014\end{array}$ & & 1968 \\
\hline
\end{tabular}

Notes: * minor storm surges (return period $<10$ years) during river/flash flood were identified in the hydrometerological data used in this study, $* *$ estuaries currently protected by storm surge barriers; *** storm surge occurred between waves of river floods (2013/2014). 